\title{
Decoupling of fluids and fluid-mobile elements during shallow subduction: Evidence from halogen-rich andesite melt inclusions from the Izu arc volcanic front
}

\author{
Susanne M. Straub \\ GEOMAR Forschungszentrum an der Christian-Albrechts Universität zu Kiel, Wischhofstrasse 1-3, 24148 Kiel, \\ Federal Republic of Germany \\ Now at Lamont Doherty Earth Observatory, Columbia University, 61 Route 9W, Palisades, New York 10964, USA. \\ (smstraub@ldeo.columbia.edu) \\ Graham D. Layne \\ Woods Hole Oceanographic Institution, MS 23, Clark 114A, Woods Hole, Massachusetts 02543, USA
}

[1] Very rare, halogen-rich andesite melt inclusions (HRA) in bytownitic plagioclase phenocrysts $\left(\mathrm{An}_{89-}\right.$ 90) from tephra fallout of the Izu arc volcanic front (Izu VF) provide new insights into the processes of fluid release from slab trenchward to the volcanic front in a cool subduction zone. These HRA are markedly enriched in $\mathrm{Cl}, \mathrm{F}$ and $\mathrm{Li}$ - by factors of up to $8(\mathrm{Cl}, \mathrm{F})$ and $1.5(\mathrm{Li})$ - but indistinguishable with respect to the fluid-mobile large-ion lithophile elements (LILE; K, Sr, Rb, Cs, Ba, Pb, U), rare earths (REE) or high field strength elements (HFSE) from the low-K tholeiitic magmas of the Izu VF. We suggest that the chemical signature of the HRA reflects the presence of a fluid in the mantle source that originated from the serpentinized mantle peridotite above the metacrust. This "wedge serpentinite" presumably formed by fluid infiltration beneath the forearc and was subsequently down-dragged with the slab to arc front depths. The combined evidence from the Izu VF ( $110 \mathrm{~km}$ above slab) and the outer forearc serpentinite seamounts ( $\sim 25$ to $30 \mathrm{~km}$ above slab) suggests that the slab flux of $\mathrm{B}$ and $\mathrm{Cl}$ is highest beneath the forearc, and decreases with increasing slab depths. In contrast, the slab flux of Li is minor beneath the forearc, but increases with depth. Fluorine may behave similarly to Li, whereas the fluid-mobile LILE appear to be largely retained in the slab trenchward from the Izu VF. Consequently, the chemical signatures of both Izu trench sediments and basaltic rocks appear preserved until arc front depths.

Components: 14,241 words, 10 figures, 5 tables.

Keywords: Izu volcanic arc; slab devolatilization; fluid-mobile elements; fractionation.

Index Terms: 1030 Geochemistry: Geochemical cycles (0330); 1065 Geochemistry: Trace elements (3670); 3640 Mineralogy, Petrology, and Mineral Physics: Igneous petrology.

Received 22 March 2002; Revised 9 April 2003; Accepted 23 April 2003; Published 8 July 2003.

Straub, S. M., and G. D. Layne, Decoupling of fluids and fluid-mobile elements during shallow subduction: Evidence from halogen-rich andesite melt inclusions from the Izu arc volcanic front, Geochem. Geophys. Geosyst., 4(7), 9003, doi:10.1029/2002GC000349, 2003.

Theme: Trench to Subarc: Diagenetic and Metamorphic Mass Flux in Subduction Zones Guest Editors: Gray Bebout and Tim Elliot 


\section{Introduction}

[2] During shallow subduction (trenchward from the volcanic front), the descending lithosphere releases large amounts of water and carbon dioxide [e.g., Kerrick and Connolly, 1998; Wallmann, 2001]. Since water is a primary transport agent for many fluid-mobile elements (e.g., $\mathrm{Li}, \mathrm{B}, \mathrm{Cl}$, $\mathrm{Cs}, \mathrm{Pb}$ ), these elements might be lost from slab during early subduction as well, implying that the composition of the subducted material changes significantly prior to reaching arc front depths [e.g., Bebout et al., 1999; Class et al., 2000]. Unfortunately, the critical region for early slab devolatilization $(<110 \mathrm{~km}$ depth) cannot be directly observed at active convergent margins since there is no concomitant volcanism. To date, the most comprehensive information on the early chemical evolution of the subducting slab derives from studies of uplifted, metamorphosed slab fragments [e.g., Bebout et al., 1999; Scambelluri et al., 2001]. In active settings, however, information on the composition of the shallow fluids can only be obtained from serpentinite seamounts, located $\sim 20-25 \mathrm{~km}$ above slab on the outer trench slope [Fryer et al., 1999; Benton et al., 2001], or from the volcanic arc, located $\sim 110 \mathrm{~km}$ above slab [e.g., Taylor and Nesbitt, 1998; Hochstaedter et al., 2001].

[3] In this study, we present data on the $\mathrm{Cl}, \mathrm{F}$ and $\mathrm{Li}$ contents of both matrix glasses and plagioclase melt inclusions from fallout tephra of the Izu arc volcanic front (Izu VF). These tephra glasses are an excellent proxy to Izu VF magma compositions (e.g., S. M. Straub, G. D. Layne, A. Schmidt and C. H. Langmuir, The recycling of fluids and sediment melts in volcanic arcs, manuscript submitted to Geochemisty Geophysics Geosystems, 2003, hereinafter referred to as Straub et al., submitted manuscript, 2003). Cl, F and $\mathrm{Li}$ are enriched in the subducting slab, owing to contributions from seawater, sediments, and basaltic oceanic crust [e.g., Ryan and Langmuir, 1987; Decitre et al., 2002]. Since $\mathrm{Cl}, \mathrm{F}$ and Li are also highly mobile in hydrothermal fluids [e.g., Schilling et al., 1978; Ryan and Langmuir, 1987; Seyfried and Ding, 1995], they should become readily entrained in fluids during early subduction. The data show that $\mathrm{Cl}, \mathrm{F}$ and Li display a much wider range in composition than the other recycled, fluid-mobile large-ion lithophile elements (LILE; K, Sr, Rb, Cs, $\mathrm{Ba}, \mathrm{Pb}, \mathrm{U}$ ) in the Izu VF magmas. In combination with existing data from the outer forearc seamounts, our results provide new insights into the sequential release of fluid-mobile elements during shallow subduction.

\section{Geological Setting}

[4] The evolution and structure of the intraoceanic Izu Bonin Mariana arc/backarc system (IBM; NW Pacific) has been described in detail elsewhere [Taylor, 1992; Hochstaedter et al., 2001]. In summary, volcanism in the Izu and Mariana arcs began at $\sim 49 \mathrm{Ma}$ (middle Eocene), following the westerly subduction of the Mesozoic $(\sim 130 \mathrm{Ma})$ Pacific plate beneath the Philippine plate. In the Oligocene $(\sim 31 \mathrm{Ma})$ the Izu arc split along-strike. During the Miocene ( 24 to $15 \mathrm{Ma}$ ), the Shikoku backarc basin formed. Volcanism at the Izu VF waned during backarc spreading, but rejuvenated $\sim 15 \mathrm{Ma}$ ago, and has since been vigorous. A new period of intraarc rifting was initiated at $\sim 2.8 \mathrm{Ma}$ immediately west of the Izu VF (Figure 1). The Quaternary Izu VF is constructed on $\sim 20 \mathrm{~km}$ thick crust [Suheyiro et al., 1996], and located about $\sim 100-110 \mathrm{~km}$ above a well-defined Wadati-Benioff zone [Katsumata and Sykes, 1969; Wicks and Richards, 1993]. The subducting crust is Cretaceous in age, with the basaltic basement being similar in composition to the mid-ocean ridge basalts of the East Pacific Rise [Fisk and Kelley, 2002]. The sediment cover consists of $\sim 400 \mathrm{~m}$ thick Mesozoic and Cenozoic pelagic clays ( $\sim 39 \%)$, arc-derived ash $(\sim 5 \%)$ and chert, nannofossil chalk and marls ( 56\%) [Plank et al., 2000].

[5] The Izu VF is an informative setting to study, since it has a highly depleted subarc mantle wedge [Taylor and Nesbitt, 1998; Langmuir et al., 2003] with no evidence of partial slab melts in the mantle source [Taylor and Nesbitt, 1998; Hochstaedter et al., 2000, 2001]. Against this background, the chemistry of slab-derived fluids is clearly recog- 


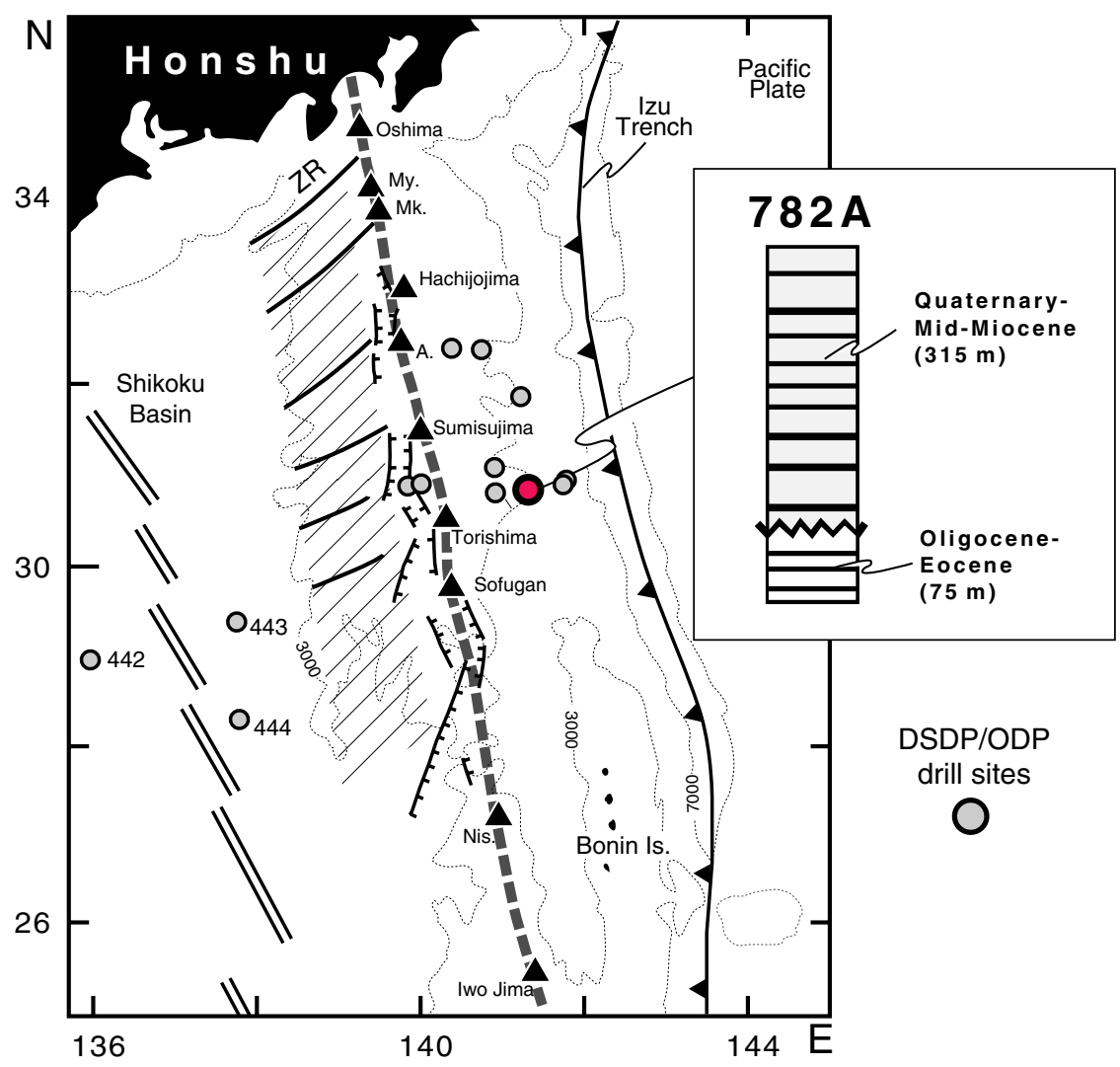

Figure 1. Geological setting of the Izu-Bonin arc/backarc system with DSDP and ODP drill sites. ODP Site 782A is indicated. From East to West: Pacific Plate, Izu Trench, Izu Forearc, Izu Volcanic Front (stippled line), rift (grabens), rear arc (hatched) and the inactive Shikoku Backarc Basin. Depth contours are in meters. ZR, Zenisu Ridge (subaerial volcanoes Nijiima and Kozushima are not shown); Subaerial volcanoes (black triangles) unless labeled are My, Miyakejima; Mk, Mikurajima; A, Aogashima; Nis, Nishinoshima. BI, Bonin islands (uplifted Eocene forearc basement). Diagonal solid lines in rear arc region denote rear-arc volcanic chains. Stratigraphy of ODP Site 782A after $X u$ and Wise [1992].

nizable. Moreover, the Izu Bonin is a classic example of a cool subduction zone, in which most of the fluid-mobile elements may be retained in the slab until arc front depths [e.g., Bebout et al., 1999]. Comprehensive studies of major and trace elements, and radiogenic isotopes $(\mathrm{Sr}, \mathrm{Nd}, \mathrm{Pb})$, have shown that (1) the composition of the mantle and slab sources have been homogenous during the last 15 million years and that (2) the Neogene Izu VF magma source is infiltrated by fluid components from both the subducting sediment $(\sim 3.5 \%$ of total fluid) and the subducting basaltic crust ( $\sim 96.5 \%$ of total fluid) [e.g., Taylor and Nesbitt, 1998; Hochstaedter et al., 2001; Straub et al., submitted manuscript, 2003]. Hydrated serpentinized peridotite, that provides additional fluid sources, is considered to be present either above [Straub and
Layne, 2002], or below, the slab [Peacock, 2001] (Figure 1). For these reasons, the Izu VF volcanics are ideally suited for an investigation of the provenance and pathways of slab-derived fluids.

\section{Samples and Methods}

[6] Halogen and Li abundances of Izu VF magmas were determined from matrix shards and melt inclusions from fallout tephra. The tephra was recovered from sediments at ODP site 782A, located $\sim 120 \mathrm{~km}$ trenchward of the Quaternary Izu VF (Figure 1). Site 782A contains numerous fallout tephras, which provide a highly resolved temporal record (one event per $0.12 \mathrm{Ma}$ on average) of Izu VF volcanism. Most of the fallout tephra investigated is of Neogene age (0.55-14.2 Ma); only a 
single Oligocene fallout tephra (29.6 Ma) was included. A comprehensive data set exists for the 782A fallout tephra. This includes bulk analyses of $\mathrm{Sr}, \mathrm{Nd}$ and $\mathrm{Pb}$ isotopes [Schmidt, 2001], as well as major and trace elements, and B isotopes, by microanalytical methods on single glass shards [Straub and Layne, 2002, 2003; Straub et al., submitted manuscript, 2003]. A representative sub-set of the glasses has been analyzed for trace elements by laser ablation-ICP-MS (Straub et al., submitted manuscript, 2003). The $\mathrm{Cl}, \mathrm{F}$ and $\mathrm{Li}$ determinations were performed, by electron microprobe $(\mathrm{Cl})$ and ion microprobe $(\mathrm{F}, \mathrm{Li})$, on the same suite of matrix glasses and melt inclusions previously analyzed for major elements (electron microprobe) and $\mathrm{B}$ isotopes (ion microprobe). The data relevant to this paper, and a short summary of the analytical procedures, is provided in Tables 1-4 for easy reference. A detailed description of the analytical procedures is given in Straub et al. (submitted manuscript, 2003) (major elements, B, Li), Straub and Layne [2002] (B isotopes) and Straub and Layne [2003] (Cl, F). None of these previous studies, however, addresses in detail the question of the origin of the halogen-rich andesite inclusions, and the potential implications for shallow slab devolatilization, which are the focus of this paper.

[7] The glasses from the Site 782A fallout tephras are mostly low-K basalts to rhyolites that are very similar in major element, trace element and isotope composition to the Quaternary Izu VF lavas. The single Oligocene tephra studied (sample 108), which was heavily disturbed by the drilling, has a subordinate population of medium-K glasses, which is not further considered here. With the exception of a single high-MgO Izu lava from the island of Hachijojima $(\mathrm{MgO}=8.23 \mathrm{wt} \% ; \mathrm{Mg} \#=$ $62)$, the tephra glasses and Izu arc front lavas have similar maximum $\mathrm{MgO}(\sim 6 \mathrm{wt} \%)$ and $\mathrm{Mg \#}$ numbers $[\sim 60$; where $\mathrm{Mg} \#=$ molar ratio $\mathrm{Mg} /(\mathrm{Mg}+$ $\left.\left.\mathrm{Fe}^{2+}\right)\right]$. Basaltic through rhyolite lava and tephra series are indistinguishable in their $\mathrm{Sr}-, \mathrm{Nd}-, \mathrm{Pb}$ - and $\mathrm{B}$ isotope ratios, demonstrating that the series are co-genetic and originate from the same sources as the Izu VF lavas [Straub et al., submitted manuscript, 2002; Straub and Layne, 2002]. Further, no evidence for post-eruptive alteration has been found. The glasses investigated are all clear, colorless to brown glass shards, or melt inclusions, without any telltale signs of birefringence under crossed polarizers or cloudiness indicative of incipient alteration. The consistency of glass and melt inclusion compositions, the apparently magmatic systematics of alteration-sensitive elements like Li and $\mathrm{B}$ (Figure 2), and the combination of high $\mathrm{B}$ $(\sim 10-40 \mathrm{ppm})$ with $\delta^{11} \mathrm{~B}$ of $+5 \%$ to $+12 \%$ in the Izu glasses, all militate against the presence of any syn- or post-eruptive seawater alteration [Straub and Layne, 2002, 2003]. Thus the high B contents and high- $\delta{ }^{11} \mathrm{~B}$ values of the normal-group glasses and the HRA demonstrate the presence of a slab component in the Izu VF magma source and imply a slab origin for other fluid-mobile elements as well.

\section{Results}

\subsection{Two Component Melts: Normal-Group Glasses and HRA}

[8] On the basis of their $\mathrm{Cl}, \mathrm{F}$ and Li contents, the Izu glasses can be divided into two groups (Figure 2). The majority of glasses and melt inclusions (termed "normal-group" glasses), contain 0.05-0.40 wt \% $\mathrm{Cl}, 70-400$ ppm F and 4-10 ppm Li. The normalgroup glasses comprise matrix glasses, and melt inclusions in plagioclase, that range from basalt to rhyolite in composition. In this group, $\mathrm{Cl}, \mathrm{F}$ and $\mathrm{Li}$ behave similarly to the fluid-mobile LILE. This means that $\mathrm{Cl}, \mathrm{F}$ and $\mathrm{Li}$ vary by about a factor of two at a given $\mathrm{MgO}$, and increase by a factor of three with decreasing $\mathrm{MgO}$ (Figure 2; in the context of this paper the term "fluid-mobile LILE" refers to $\mathrm{Cs}, \mathrm{Rb}, \mathrm{Ba}, \mathrm{U}, \mathrm{K}, \mathrm{B}, \mathrm{Sr}$ and $\mathrm{Pb}$ ). In contrast, the second group of glasses ("halogen-rich inclusions"; $=$ HRA) consists of rare andesite melt inclusions in plagioclase (Figures 2-4). The HRA are selectively enriched in the halogens $\mathrm{Cl}(0.70-0.86 \mathrm{wt} \%)$, and $\mathrm{F}$ (700-900 ppm) by about a factor of 8 . The abundance of $\operatorname{Li}(\sim 15 \mathrm{ppm})$ is increased by about a factor of 1.5 , excepting a single HRA melt inclusion that has a 'normal' Li content (Figure 2). The HRA were found in only three out of forty of the 782A tephras investigated. In these three tephras, the HRA are readily identified by their characteristic $\mathrm{Cl}$ enrich- 


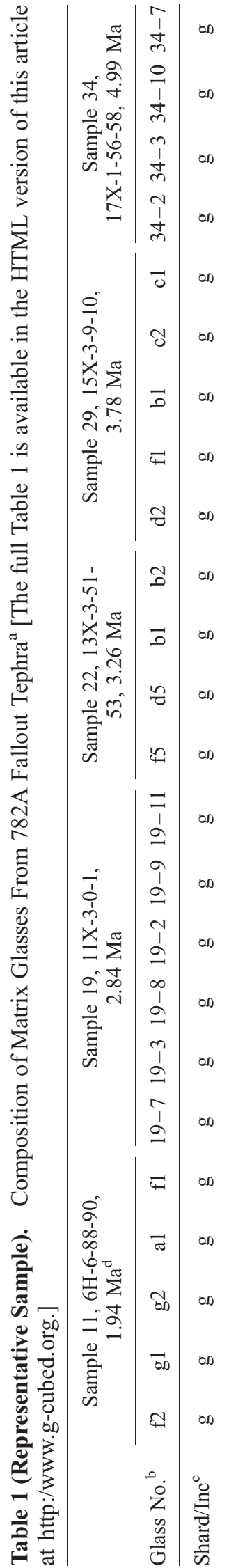

กิ8으요

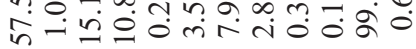

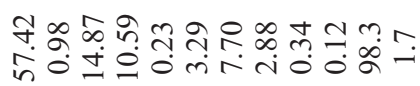

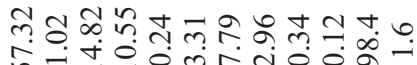

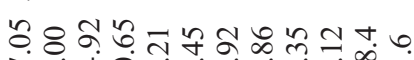

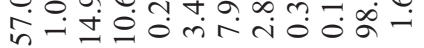

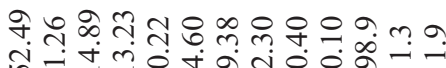

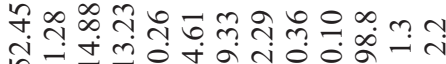

ஸे ํํำ

तु-

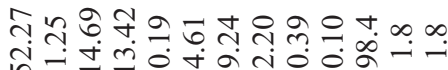

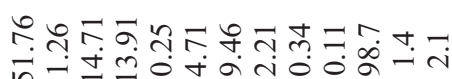

तेt 뉴요

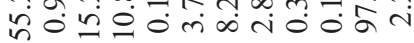

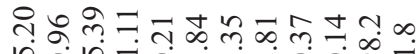

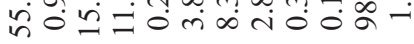

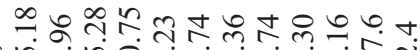

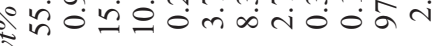

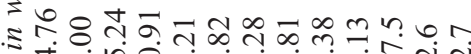

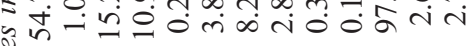

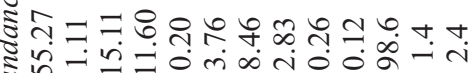

\&ี

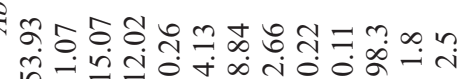

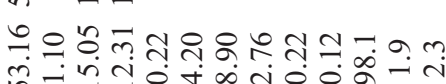

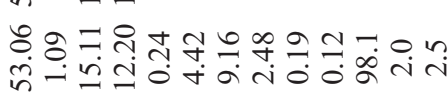

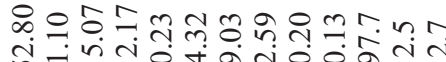

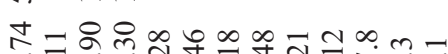

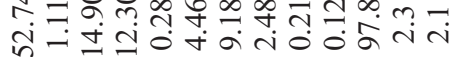

m

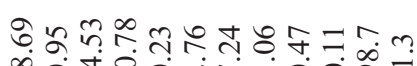

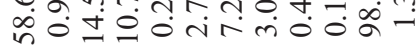

กิ

n-nomn $n-0$

กั०

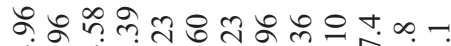

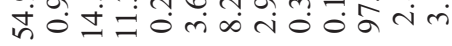

全部

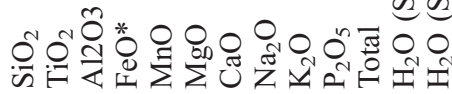

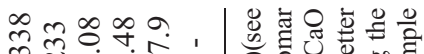

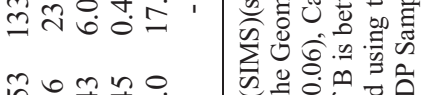

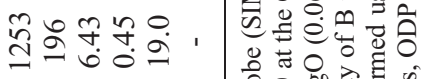

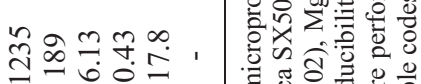

กิษ

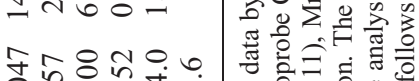

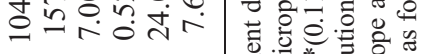

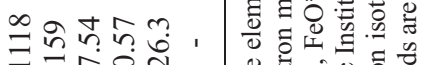

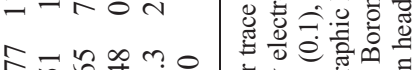

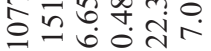

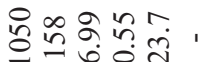

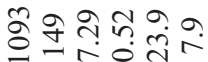

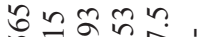

능ํㄷ

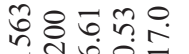

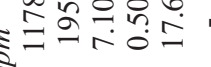

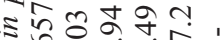

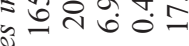

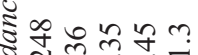

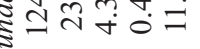

से

สิธี

\&

तोo

તิڤ

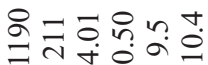

응워웡

으요 f ₹

min $\infty$ ?

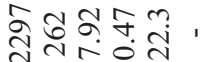

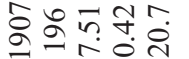

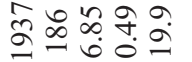

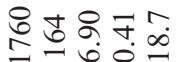

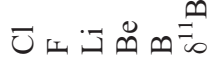

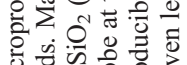

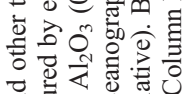

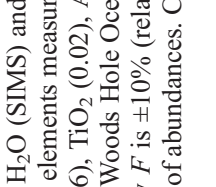

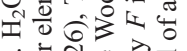

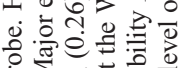

药

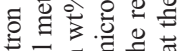

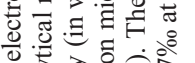

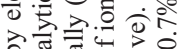

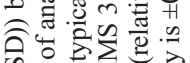

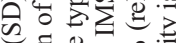

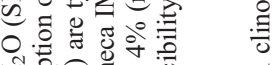

I.

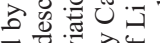

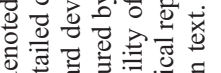

ठ

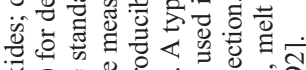

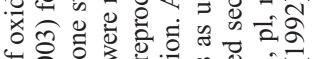

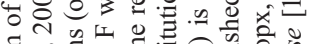

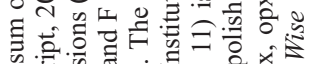

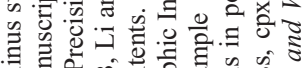

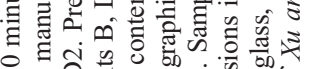

8

능

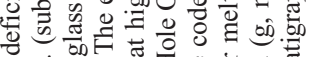

㱦

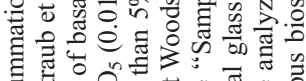

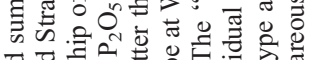

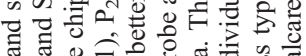

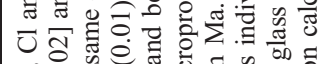

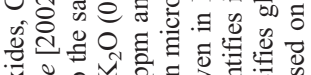

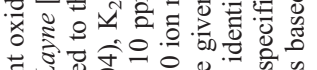

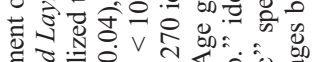
क

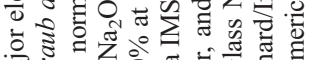

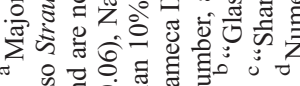




\begin{tabular}{|c|c|c|c|c|c|c|}
\hline & $\stackrel{\sqrt[n]{\infty}}{\stackrel{\infty}{+}}$ & $\bar{a}$ & în & & 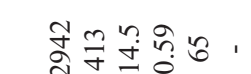 & \\
\hline & $\stackrel{\infty}{\stackrel{\infty}{+}}$ & $\bar{c}$ & $\begin{array}{l}\hat{b} \\
m \\
\infty\end{array}$ & & 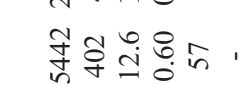 & \\
\hline & 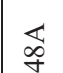 & $\bar{a}$ & 守 & & 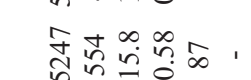 & \\
\hline & 空 & $\bar{a}$ & +o & & 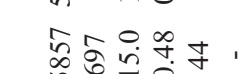 & \\
\hline & & - & 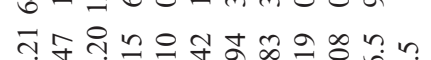 & & & \\
\hline & 于 & $\bar{z}$ & त० mo & & & \\
\hline & 学 & $\overline{2}$ & 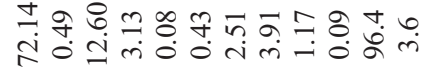 & & 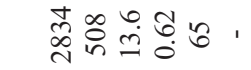 & \\
\hline & 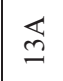 & $\overline{2}$ & 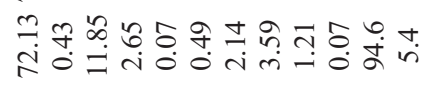 & & 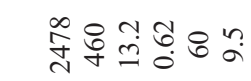 & \\
\hline & 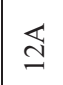 & $\bar{a}$ & 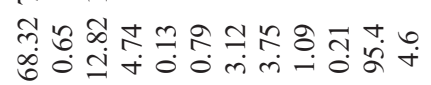 & & 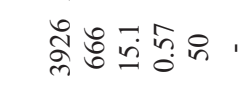 & \\
\hline & $\Xi$ & $\overline{2}$ & 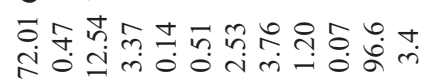 & & 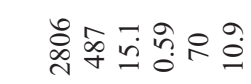 & \\
\hline$\sum^{\pi}$ & $\stackrel{1}{\Xi}$ & $\bar{\Omega}$ & 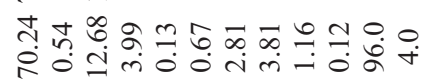 & & 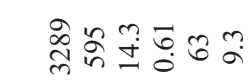 & \\
\hline ñ & 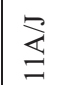 & $\overline{2}$ & 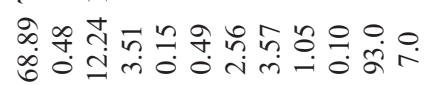 & & 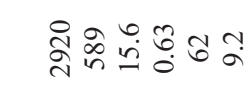 & \\
\hline 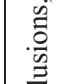 & $\cong$ & $\bar{a}$ & 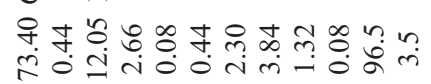 & & 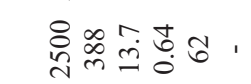 & \\
\hline = & $\overleftarrow{\Xi}$ & $\overline{2}$ & 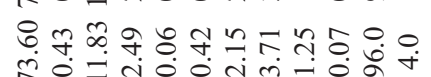 & & 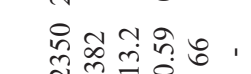 & \\
\hline$\sum^{\bar{e}}$ & 떵 & $\bar{a}$ & 号守 & & in & \\
\hline & 0 & $=$ & & & & \\
\hline & 6 & 2 & 에 & & 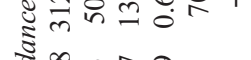 & \\
\hline & Uુ & $\bar{z}$ & त̂n & & 离 & \\
\hline & $\ddot{6}$ & $\overline{2}$ & 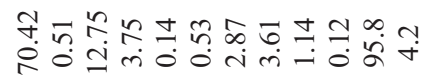 & & 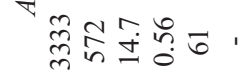 & \\
\hline & $\bigoplus$ & $\bar{a}$ & 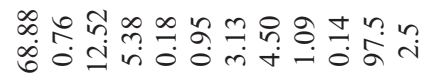 & & mã̃ & \\
\hline & 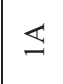 & $\bar{\Omega}$ & 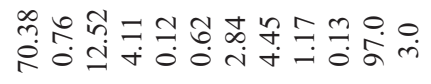 & & 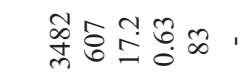 & \\
\hline & $\underline{n}$ & 右 & 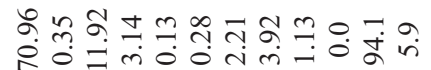 & & 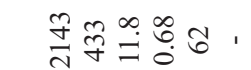 & \\
\hline & $\underset{\infty}{\infty}$ & 参 & 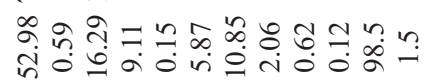 & $\stackrel{+}{\rightarrow}$ & సૈ. & \\
\hline & $\underset{\infty}{\mathbb{\infty}}$ & 育 & 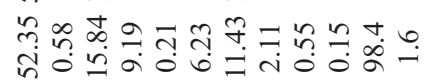 & $\stackrel{0}{-}$ & 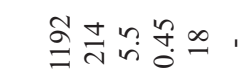 & \\
\hline & 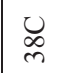 & 彥 & 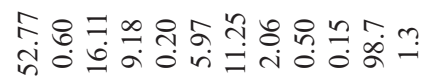 & $\stackrel{\circ}{\circ}$ & 吉垴守导こ. & \\
\hline$\sum^{\pi}$ & fo & סמס & 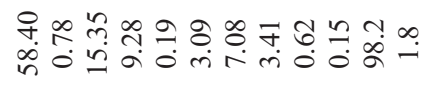 & & 픈조유. & \\
\hline ñ & 导 & מם & 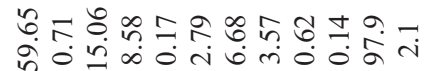 & & 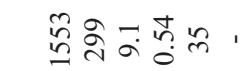 & \\
\hline 袍 & 웅 & מם & 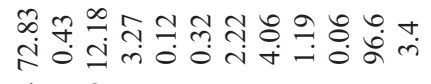 & & 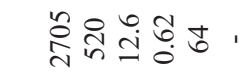 & \\
\hline 宸 & 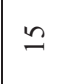 & מם & 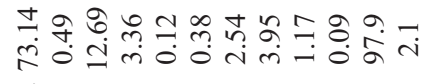 & & $\underset{\dot{I}}{\stackrel{5}{0}}$ & \\
\hline & 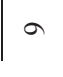 & & 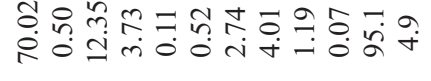 & & 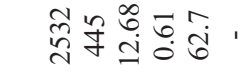 & \\
\hline & & & 0 & $0 \leq$ & 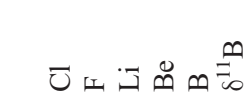 & \\
\hline
\end{tabular}




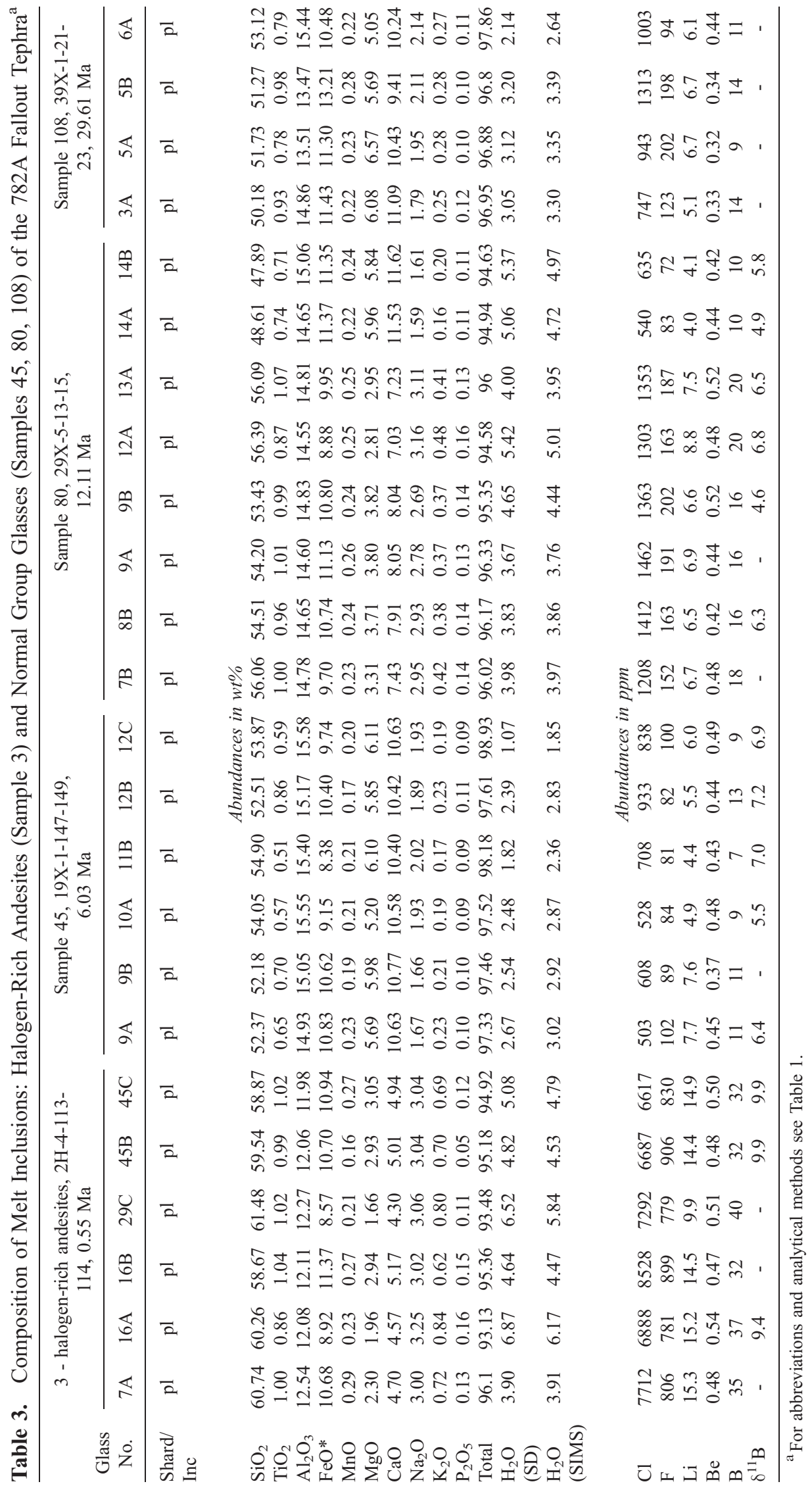




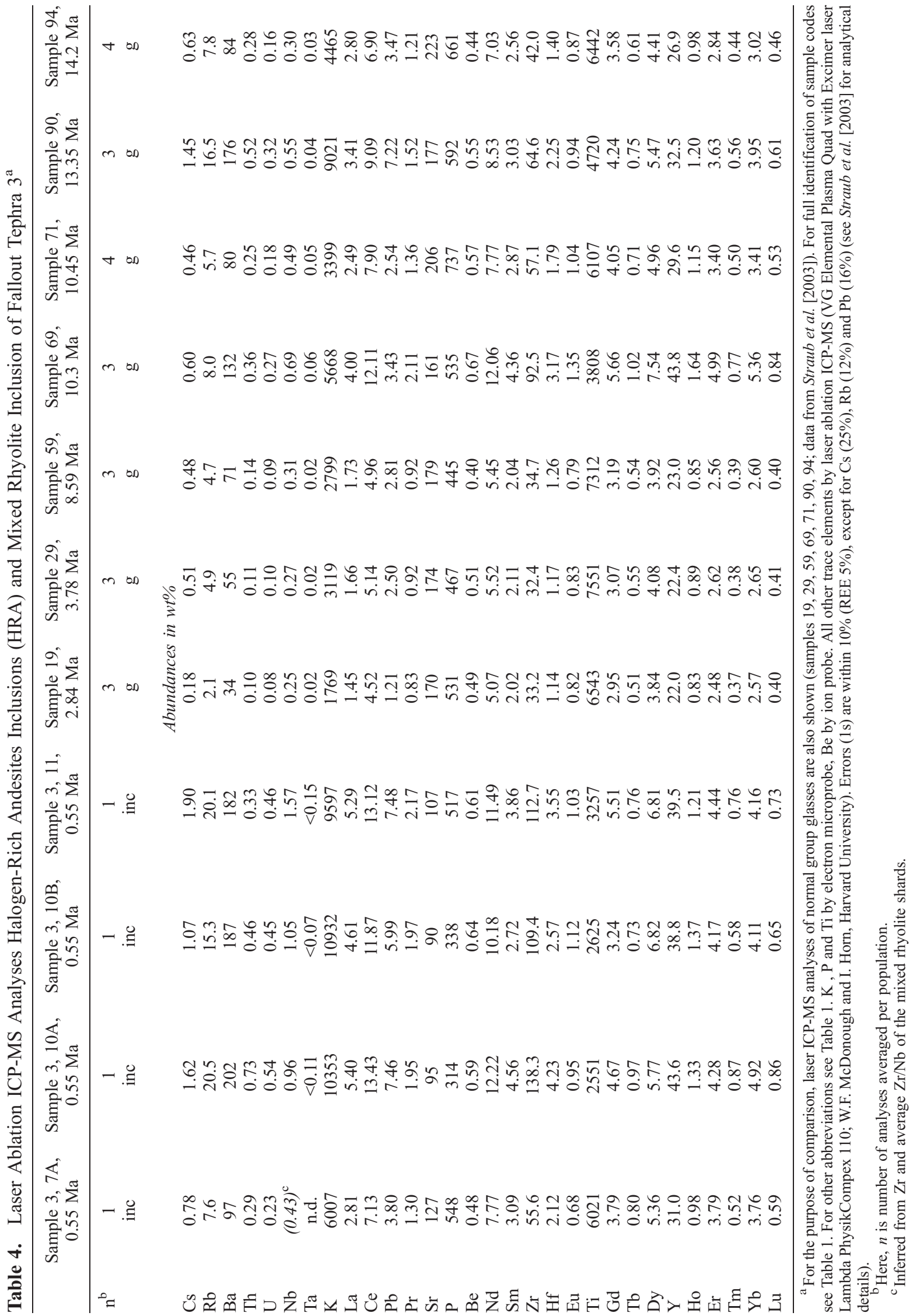




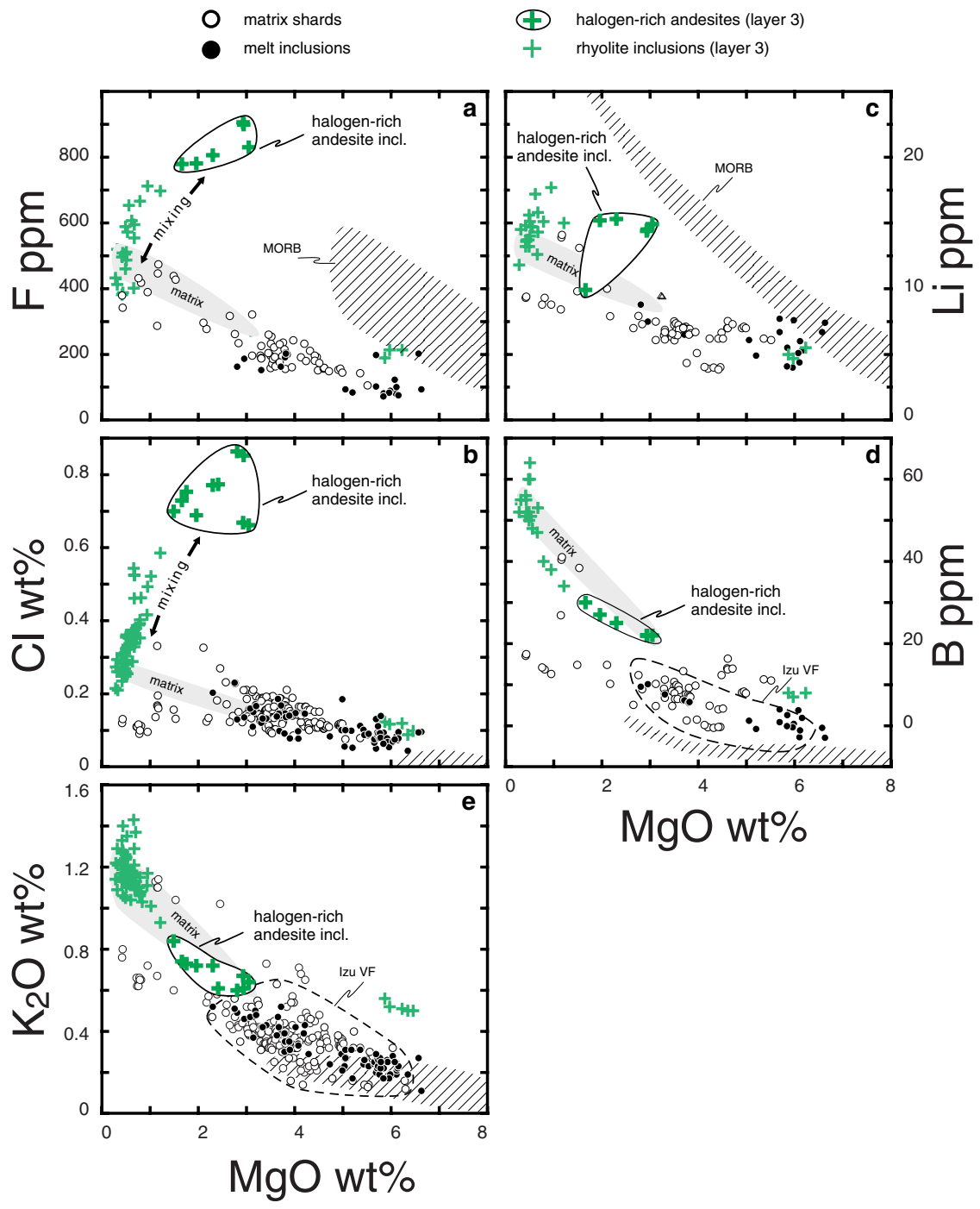

Figure 2. Variations of $\mathrm{F}, \mathrm{Cl}, \mathrm{Li}, \mathrm{K}_{2} \mathrm{O}$ and $\mathrm{B}$ versus $\mathrm{MgO}$ in the Izu VF glasses. The normal-group glasses (melt inclusions are filled circles; matrix glasses are open circles; grey field denoted "matrix" indicated matrix shards in sample 3) display a general enrichment in these elements with decreasing $\mathrm{MgO}$. The halogen-rich andesite (HRA) inclusions (bold green crosses) are selectively enriched in Cl, F and Li. Mixed rhyolite inclusions (green crosses) lie along apparent mixing trends between the HRA and normal-group rhyolite glasses. The fields for N-MORB are from Ryan and Langmuir [1987] and Ryan and Langmuir [1993] (B, Li), and Michael and Cornell [1998] (Cl, K). The Cl reference field is for depleted MORB with $\mathrm{Cl} / \mathrm{K}<0.08$. Izu VF after Ryan and Langmuir [1993], Taylor and Nesbitt [1998] and Langmuir et al. [2003].

ments and high $\mathrm{Cl} / \mathrm{K}_{2} \mathrm{O}$ ratios. However, only one fallout tephra (layer 3 at $0.55 \mathrm{Ma}$ ) contained melt inclusions that are large enough (up to $100 \mathrm{mi}-$ crometer diameter) for the analysis of trace elements and $\mathrm{B}$ isotopes by laser ablation-ICPMS and ion microprobe, respectively. These latter analyses show that the normal-group glasses and the HRA are indistinguishable in all other incompatible trace elements, and in the B isotopes [Straub and Layne, 2002, 2003]. In each fallout tephra layer, the HRA always constitute a minor portion $(<1$ vol. $\%)$ of the entire melt inclusion population in the plagioclases. The HRA are always included within bytownitic $\left(\mathrm{An}_{89-90}\right)$ plagioclase cores, the most calcic plagioclase compositions present in any given fallout tephra (Figures $4 \mathrm{a}$ and $4 \mathrm{~b})$. The bytownitic cores are always mantled by labradoritic $\left(\sim \mathrm{An}_{50-60}\right)$ rims. These rims commonly contain "mixed" dacitic and rhyolitic melt inclusions, that lie on apparent mixing 


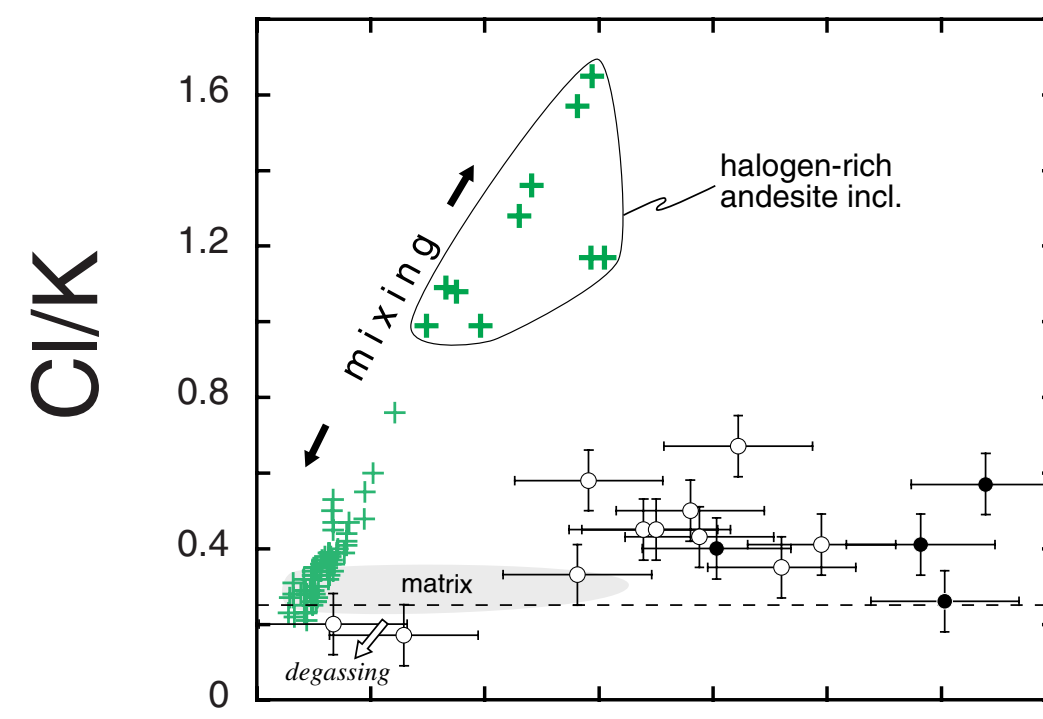

a

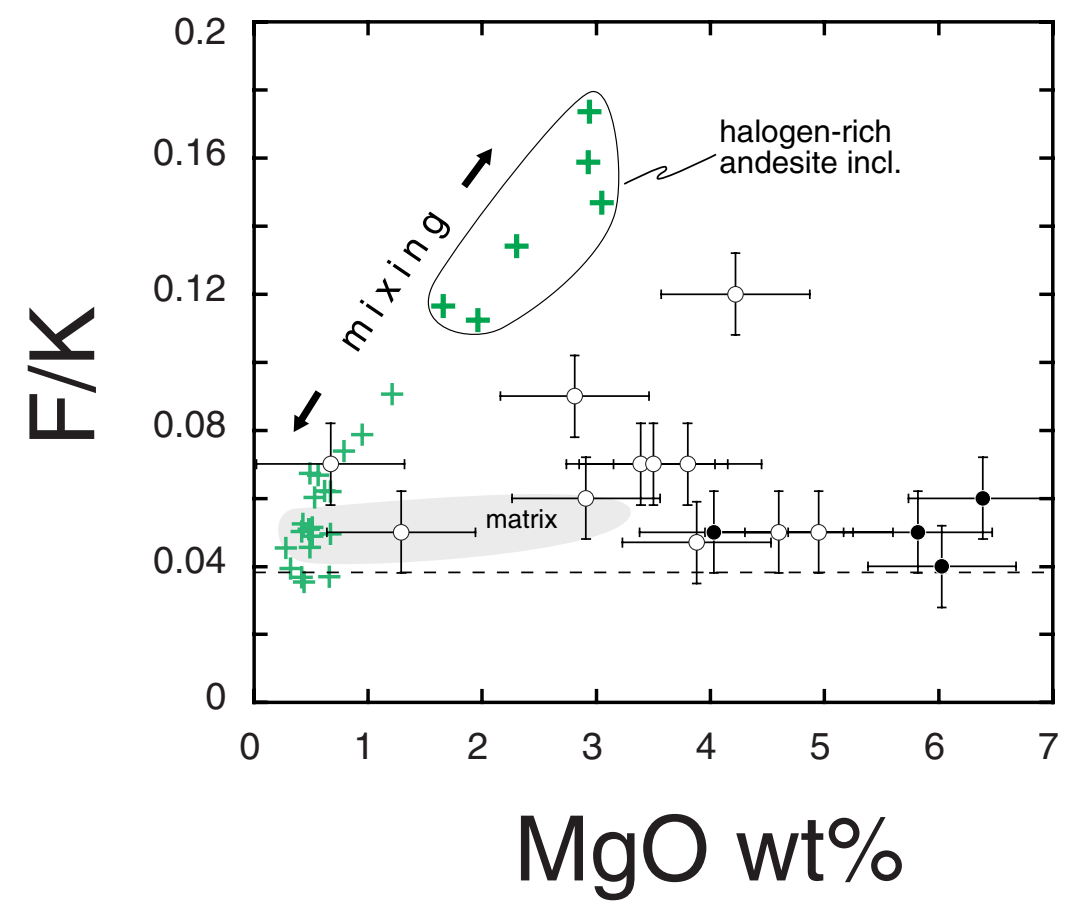

Figure 3. $\mathrm{Cl} / \mathrm{K}$ and $\mathrm{F} / \mathrm{K}$ versus $\mathrm{MgO}$ of the Izu VF glasses. Symbols as in Figure 2. Horizontal stippled lines are the minimum $\mathrm{Cl} / \mathrm{K}$ and $\mathrm{F} / \mathrm{K}$ ratios of the normal-group glasses. No decrease in $\mathrm{Cl} / \mathrm{K}$ and $\mathrm{F} / \mathrm{K}$ with decreasing $\mathrm{MgO}$ is apparent, implying that only a single, $\mathrm{Cl}$ - and F-poor, aqueous vapor phase was exsolved, resulting in no significant loss of halogens. Only the most siliceous normal-group glasses fall below this perceived minimum for $\mathrm{Cl} / \mathrm{K}$ (white arrow), which is attributed to the incipient exsolution of hypersaline brine, producing substantial depletion of melt $\mathrm{Cl}$.

trends between the lowest $\mathrm{MgO}$ normal-group rhyolite glasses and the HRA (Figures $4 \mathrm{a}$ and $4 \mathrm{~b}$ ).

\subsection{The Effects of Fractionation}

[9] In the low-K Izu VF magmas, Li, Be, B, F, Cl, and $\mathrm{K}$ all have bulk partition coefficients $<1$ with respect to the observed mineral assemblage, which is dominated by plagioclase and pyroxene. The D's are, in decreasing order; $\mathrm{D}_{\mathrm{F}} \sim 0.8, \mathrm{D}_{\mathrm{Cl}} \sim 0.54, \mathrm{D}_{\mathrm{Be}}$ $\sim 0.27, \mathrm{D}_{\mathrm{B}} \sim 0.09$ and $\mathrm{D}_{\mathrm{K}} \sim 0.09$, based on a compilation of the most recent partitioning data from Bindeman et al. [1998], Brenan et al. [1998] and Dunn and Sen [1994] (see Straub and Layne 


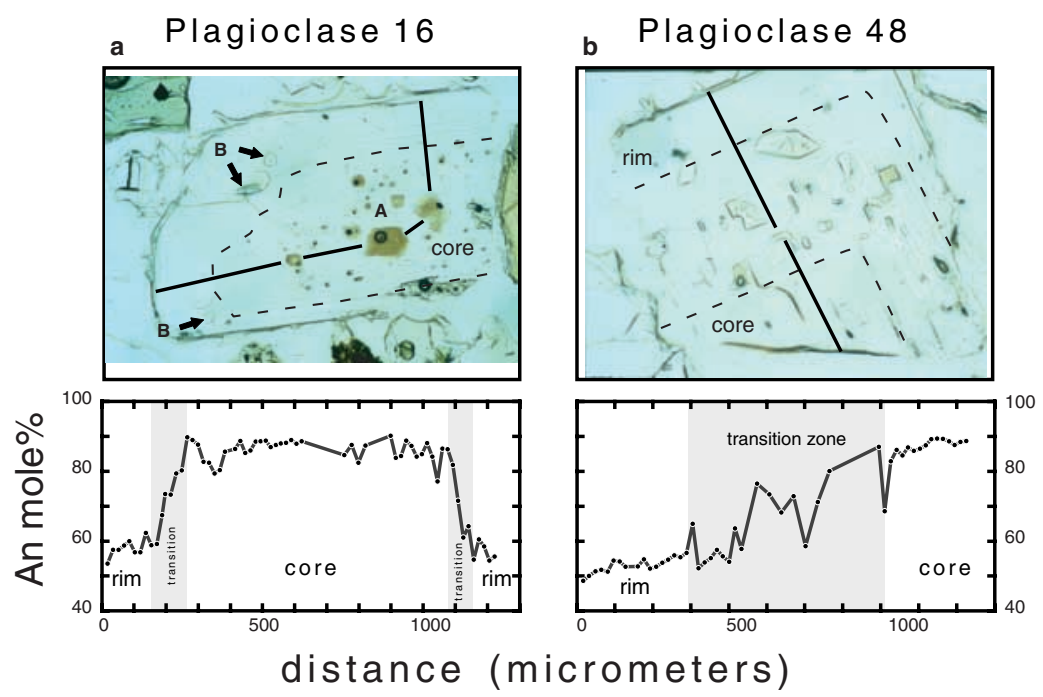

Figure 4. Photomicrographs of plagioclase phenocrysts with HRA and mixed rhyolite inclusions in fallout tephra 125-782A-2H-4-113-114 (= tephra sample 3 at $0.55 \mathrm{Ma}$ ). Each fragment is approximately one millimeter across. (a) A broad core $\left(\sim \mathrm{An}_{89-90}\right)$ contains several brown, translucent HRA melt inclusions. Bubbles indicate fluid exsolution. The rim is a sodium-rich labradorite of $\sim \mathrm{An}_{55-60}$, containing several colorless inclusions of mixed rhyolite (B with arrows). Note abrupt transition from core to rim with a drop of $\sim 30 \mathrm{~mole} \% \mathrm{An}$. (b) A broad, meshtextured transition zone with mixed rhyolite inclusions separates a typically calcic core $\left(\mathrm{An}_{88-89}\right.$ but without HRA) from a labradoritic rim $\left(\sim \mathrm{An}_{55}\right)$.

[2003] for more details). Thus these elements are not perceptibly fractionated from each other during melt crystallization as the degree of crystallization at the Izu VF is likely less than $70 \%$ [e.g., Langmuir et al., 2003; Straub and Layne, 2003]. Olivine, which is present in the Izu VF lavas, but not in the tephras, does not appreciably fractionate these elements either. Apatite can take up $\mathrm{Cl}$ and $\mathrm{F}$, but it occurs in small quantities ( $<1$ vol.\%) in highsilica glasses only, and has no perceptible effect on the halogen content of the melt [Straub and Layne, 2003]. Further, the halogens are not fractionated by degassing, although the Izu melts do lose up to several wt.\% magmatic $\mathrm{H}_{2} \mathrm{O}$ at upper crustal levels [Straub and Layne, 2003]. This can be shown by ratioing $\mathrm{Cl}$ and $\mathrm{F}$ to $\mathrm{K}$, an incompatible, nonvolatile trace element (Figure 3). Note that the vesicular, dacitic $(<2 \mathrm{wt} \% \mathrm{MgO})$ matrix shards of the normal-group have the same minimum $\mathrm{Cl} / \mathrm{K}$, $\mathrm{F} / \mathrm{K}$ and $\mathrm{Li} / \mathrm{K}$ (not shown) ratios as undegassed basaltic melt inclusions, which effectively precludes substantiative halogen loss by degassing. Consequently, the wide range of $\mathrm{Cl} / \mathrm{K}, \mathrm{F} / \mathrm{K}$ and $\mathrm{Li} / \mathrm{K}$ observed in the glasses should reflect mantle source heterogeneity.
[10] It is not clear whether the parental melts of the HRA are basaltic or andesitic as both are primary melts in subduction zones [e.g., Hirose, 1997; Carmichael, 2002; Tamura and Tatsumi, 2002]. As to the $\mathrm{Cl} / \mathrm{K}, \mathrm{F} / \mathrm{K}$ and $\mathrm{Li} / \mathrm{K}$ ratios considered, this question is not relevant, since the effects of fractional crystallization on these ratios are negligible at any rate. We note, however, that Kohut et al. [2002] report high $\mathrm{Cl}$ contents $(\sim 0.8 \mathrm{wt} \%)$ in basaltic melt inclusions in olivine phenocrysts from the submarine Southern Mariana arc, demonstrating that such $\mathrm{Cl}$ enrichments can exist in basaltic melts as well.

\subsection{Sources of $\mathrm{Cl}, \mathrm{F}$ and $\mathrm{Li}$ at the $\mathrm{Izu} \mathrm{VF}$}

[11] In Figure 5, Cl, F and $\mathrm{Li}$ are compared to the other incompatible elements. As the recycled fluidmobile LILE (Cs, Ba, Rb, B, U, Th, K, Pb, Sr), the halogens, and $\mathrm{Li}$, are substantially enriched relative to non-fluid-mobile incompatible elements $(\mathrm{Nb}$, $\mathrm{Ta}, \mathrm{Zr}$, Hf, middle and heavy REE). Given the high degree of melting beneath the Izu VF ( 2025\% [Plank and Langmuir, 1988; Hochstaedter et al., 2000], significant fractionation of the incompatible elements during mantle melting can be 


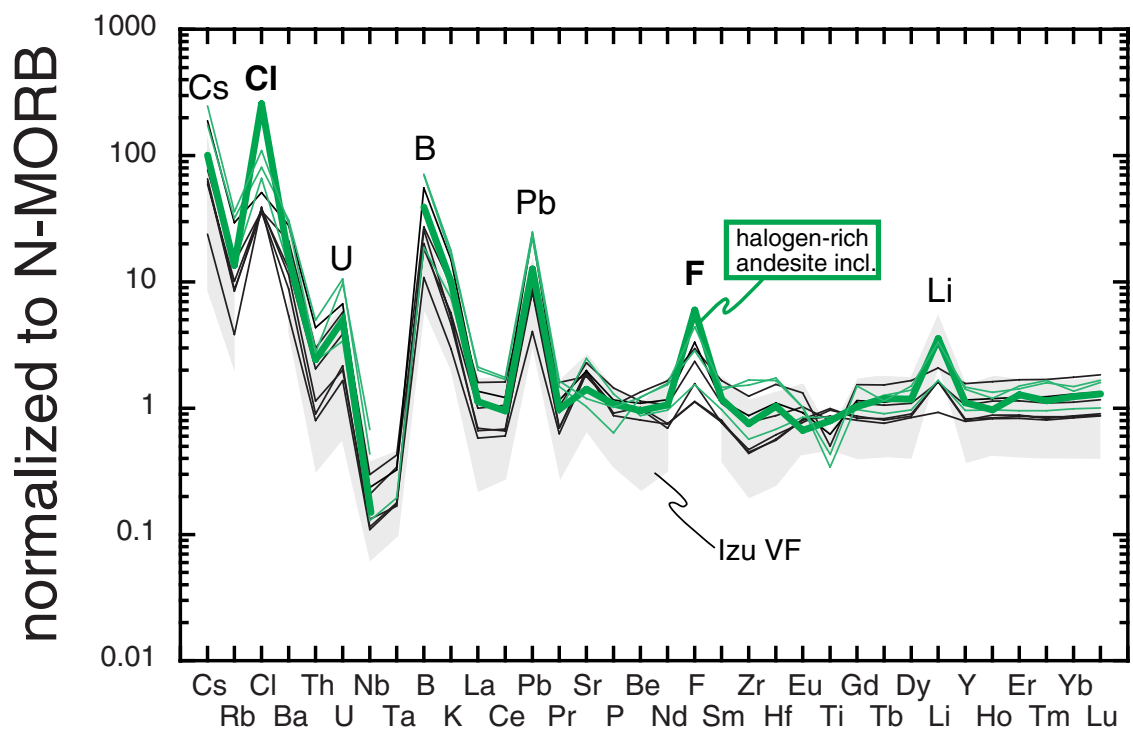

Figure 5. Incompatible elements in Izu VF glasses measured by LA-ICPMS. Thick green line denotes halogen-rich andesite inclusions (Ta below detection limit), thin lines are normal-group glasses (black) and mixed rhyolites (green), respectively. Izu VF after Taylor and Nesbitt [1998] and Langmuir et al. [2003].

excluded. Therefore assuming that the excess enrichments relative to similarly incompatible, but non-recycled elements (e.g., $\mathrm{Nb}$, Ta, middle and heavy REE) are due to slab additions, the percentages of $\mathrm{Cl}, \mathrm{F}$ and $\mathrm{Li}$ added from slab can be calculated using a simple mass balance model:

$$
\mathrm{c}_{\mathrm{VF}}=\mathrm{c}_{\mathrm{BM}} * 0.975+\mathrm{c}_{\mathrm{SF}} * 0.025
$$

whereby $\mathrm{c}_{\mathrm{VF}}=$ concentration of an element in Izu VF mantle source, $\mathrm{c}_{\mathrm{BM}}=$ concentration in the Izu background mantle, $\mathrm{c}_{\mathrm{SF}}=$ concentration in the slab fluid (Straub et al., submitted manuscript, 2003). In this simplified model, the slab fluid is considered as single component, although it might gain elements from several slab sources (e.g., metasediment, metabasalt, wedge and serpentinite). The "Izu VF mantle" source is the subarc mantle that is metasomatized by the fluid from the slab. The "Izu background mantle" is the Izu VF source minus the additions from the slab. The mixing ratio of background wedge $(\sim 97.5 \%)$ and slab fluid $(\sim 2.5 \%)$ has been inferred previously from $\mathrm{Pb}$ and $\mathrm{Pb}$ isotope modeling (Straub et al., submitted manuscript, 2003). The details of the calculations, including the determination of Izu VF source and background mantle compositions, can be found in Straub et al. (submitted manuscript, 2003), and are not reiterated here. The end-member compositions needed, however, are listed in Table 5 for easy reference. In summary, these calculations show that $>99 \%$ of $\mathrm{Cl}, \sim 60 \%$ of $\mathrm{F}$ and $\sim 34 \%$ of $\mathrm{Li}$ in the normal-group glasses are derived from slab; the remainders derive from the subarc mantle wedge. In the HRA component melt, the percentages of slab-derived $\mathrm{Cl}, \mathrm{F}$ and $\mathrm{Li}$ are higher, being $\sim 99.9 \%$ $\mathrm{Cl}, \sim 92 \% \mathrm{~F}$ and $\sim 76 \% \mathrm{Li}$, respectively.

\subsection{Mixing Systematics of Normal-Group Glasses and HRA}

[12] Ratioing $\mathrm{Cl}, \mathrm{F}$ and Li to similarly incompatible elements, that derive either from the slab or the subarc wedge, highlights source characteristics (Figures 6 and 7). The most important information gained from these diagrams, is that - in terms of $\mathrm{Cl}$, $\mathrm{F}$ and $\mathrm{Li}$ - a compositional spectrum of fluids exists that is derived from at least two subarc mantle sources (Figure 6). The element Be was chosen as incompatible wedge-derived element, since it has been analyzed in all glasses investigated by ion microprobe, in contrast to the other wedge-derived elements (e.g., $\mathrm{Nb}$, middle and heavy REE). Two observations show that Be has no significant slab addition at the Izu VF: (1) the Be content of Izu VF glasses and lavas are both significantly lower than 


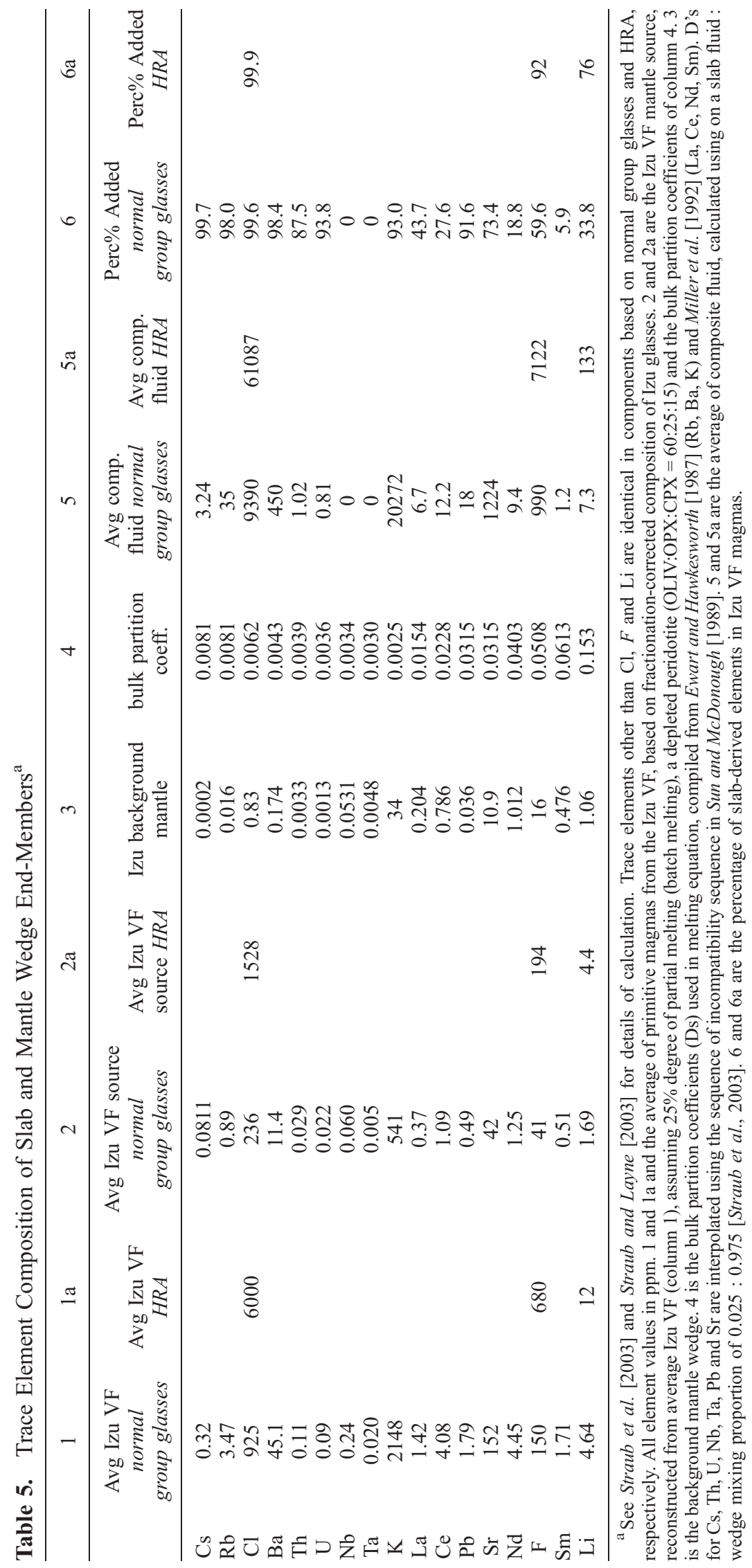




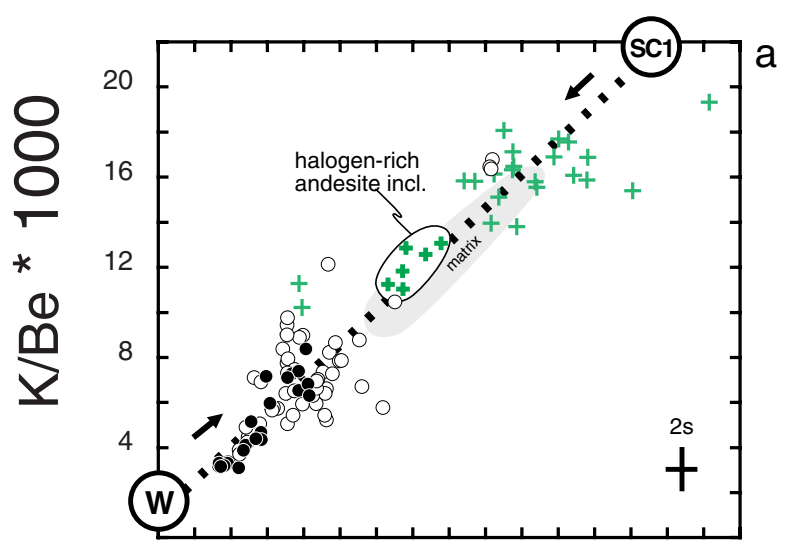

argues against the two fluids infiltrating separate subarc mantle domains at different times. Rather, the two fluids must infiltrate the Izu VF more or less simultaneously becoming mixed until at crustal levels the melts are nearly homogenized. This is consistent with the petrographic features, which strongly suggest that the HRA are relicts of the pre-aggregated andesitic component melts, that subsequently mixed with the far more numerous normal-group melt batches. In most cases the
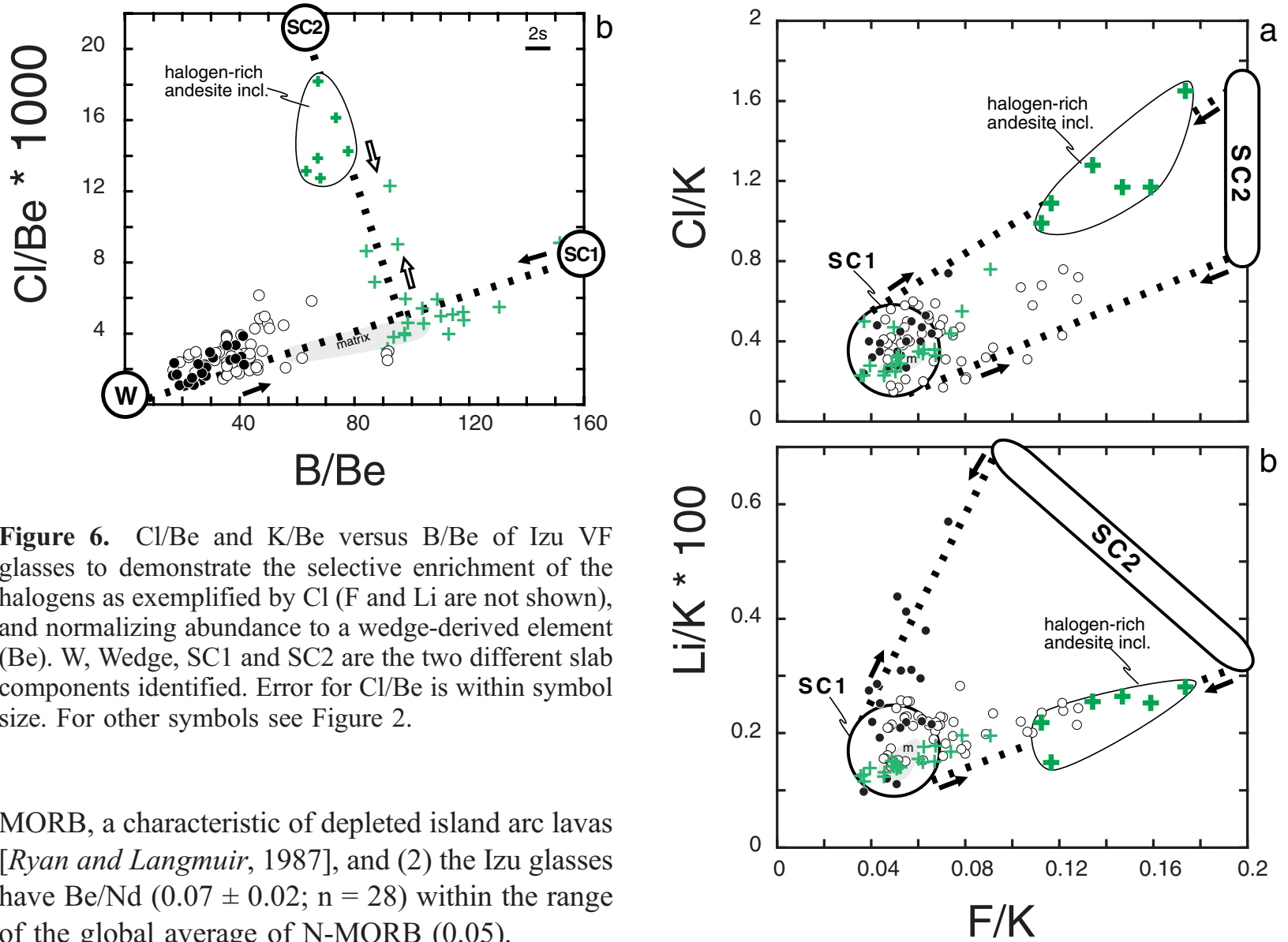

Figure 6. $\mathrm{Cl} / \mathrm{Be}$ and $\mathrm{K} / \mathrm{Be}$ versus $\mathrm{B} / \mathrm{Be}$ of $\mathrm{Izu} \mathrm{VF}$ glasses to demonstrate the selective enrichment of the halogens as exemplified by $\mathrm{Cl}$ ( $\mathrm{F}$ and $\mathrm{Li}$ are not shown), and normalizing abundance to a wedge-derived element (Be). W, Wedge, $\mathrm{SC} 1$ and $\mathrm{SC} 2$ are the two different slab components identified. Error for $\mathrm{Cl} / \mathrm{Be}$ is within symbol size. For other symbols see Figure 2.

MORB, a characteristic of depleted island arc lavas [Ryan and Langmuir, 1987], and (2) the Izu glasses have $\mathrm{Be} / \mathrm{Nd}(0.07 \pm 0.02 ; \mathrm{n}=28)$ within the range of the global average of N-MORB (0.05).

[13] Normalizing $\mathrm{Cl}, \mathrm{F}$ and $\mathrm{Li}$ to Be identifies two slab components: Slab component 1 (SC1) that is present in the source of all normal-group glasses, and slab component 2 (SC2), an additional fluid component in the source that is selectively enriched in $\mathrm{Cl}, \mathrm{F}$ and $\mathrm{Li}$ (Figure 6b). Interestingly, in Figure 6b, the linear mixing trend from SC2 (represented by the HRA) does not trend toward the depleted mantle wedge (W), but toward the rhyolite melts of the normal-group glasses. This

Figure 7. $\mathrm{Cl} / \mathrm{K}$ and $\mathrm{Li} / \mathrm{K}$ versus $\mathrm{F} / \mathrm{K}$ of Izu $\mathrm{VF}$ glasses to illustrate the compositional variability of the two slab components. The slab component infiltrating the mantle source of the normal-group glasses (SC1) has an inherent variability (large circle); m, matrix shards. For other symbols see Figure 2. Note the clearly manifested mixing line of HRA (bold green crosses) and mixed rhyolite inclusion (thin green crosses). However, not all trends emanating from this end-member trend toward the HRA, indicating that the selectively enriched second slab component ( $\mathrm{SC} 2$ ) is much more variable than indicated by the HRA of fallout tephra 3 . 
subordinate HRA component melt apparently did not survive the mixing process, and faded into the normal-group melt. If so, the significant range in $\mathrm{Cl} / \mathrm{Be}$ (Figure 6) (as well as in $\mathrm{F} / \mathrm{Be}$ and $\mathrm{Li} / \mathrm{Be}$, not shown) of the normal-group glasses can be interpreted as a "remnant signal," produced by the preeruptive mixing of these multiple component melts.

[14] Normalizing $\mathrm{Cl}, \mathrm{F}$ and $\mathrm{Li}$ to another slabderived element (e.g., K) further highlights the compositional variability of these slab fluids. In the $\mathrm{F} / \mathrm{K}$ versus $\mathrm{Cl} / \mathrm{K}$ diagram (Figure $7 \mathrm{a}$ ), the data plot in a broad band, extending from the normalgroup glasses ( $\mathrm{SC} 1$ with low $\mathrm{Cl} / \mathrm{K}$ and $\mathrm{F} / \mathrm{K}$ ) toward SC2 (HRA), which has high $\mathrm{Cl} / \mathrm{K}$ and $\mathrm{F} / \mathrm{K}$ (Figure 7). The array is roughly linear, confirming the existence of two, partially mixed, endmember components. However, having a rather limited range, the mixed rhyolites and HRA appear to represent an example of this array only, implying that the $\mathrm{Cl} / \mathrm{F}$ of SC2 (HRA) could be even lower. The heterogeneity of the HRA fluid (SC2) is more evident in $\mathrm{F} / \mathrm{K}$ versus $\mathrm{Li} / \mathrm{K}$ space (Figure $7 \mathrm{~b}$ ). Apparently, halogen-rich fluids can have very variable Li contents, showing that the $\mathrm{Li}$ enrichment is not strictly coupled to the halogen flux. Because of its high $\mathrm{Cl}$ and F contents, SC2 (HRA) must affect the halogen contents of the entire spectrum of fluids, even if present in much smaller quantity than the SC1 component. This would also explain why, in the normal-group Izu glasses, the paired correlations of $\mathrm{Cl}$ and $\mathrm{F}$ with the other fluidmobile LILE are substantially poorer than the correlations of the fluid-mobile LILE with each other.

\section{Discussion}

\subsection{Origin by Assimilation at Upper Crustal Levels?}

[15] In the preceding section, we implied that the $\mathrm{Cl}, \mathrm{F}$ and $\mathrm{Li}$ variations in the Izu VF tephras reflect mantle source signatures. However, similarly elevated $\mathrm{Cl}$ contents are found in basaltic glasses and melt inclusions from intraplate and backarc environments [Michael and Schilling, 1989; Kent et al., 2002; Lassiter et al., 2002], where they have been attributed to the assimilation of seawater, or seawater-altered crust, at upper crustal levels. Nonetheless, the more extensive data set collected for the Izu glasses, including B, F and Li concentrations, does not support an assimilation model.

[16] Assimilation of a seawater-derived brine must be ruled out, since the chemical signatures of the Izu glasses (both normal-group glasses and HRA) differ so strongly from seawater. Seawater has high $\mathrm{Cl}$ (19500 ppm), versus relatively low abundances of $\mathrm{F}$ (1.3 ppm), Li (0.18 ppm), and B (4.4 ppm). In contrast, the $\mathrm{F}(\sim 100-800 \mathrm{ppm})$ and $\mathrm{Li}(\sim 5-$ $15 \mathrm{ppm})$ abundances of the Izu glasses are much higher relative to their $\mathrm{Cl}$ contents $(\sim 1000-$ $8000 \mathrm{ppm}$ ). Current data indicate that seawater processing within the oceanic crust does not produce fluids with the appropriate chemical signature either. For example, Cl-rich hydrothermal fluids become progressively enriched in $\mathrm{Li}$ (as well as the other alkalis, like $\mathrm{Rb}$ and $\mathrm{Cs}$ ), but their $\mathrm{B}$ and $\mathrm{F}$ abundances remain close to those of seawater [e.g., Von Damm, 1995]. Thus if such a fluid impregnated the crust, from which HRA component melt was subsequently produced by partial fusion, considerable fractionation during melting would be required, the details of which are not clear [e.g., Lassiter et al., 2002].

[17] Another apparent problem concerns the amount of $\mathrm{Cl}, \mathrm{F}, \mathrm{Li}$ and $\mathrm{B}$ that can be assimilated. The normal-group glasses have $\mathrm{Cl}, \mathrm{F}, \mathrm{Li}$ and $\mathrm{B}$ abundances that are common in arc magmas worldwide [Ryan and Langmuir, 1993; Sisson and Layne, 1993; Cervantes and Wallace, 2003]. Assimilation of several hundred ppm $\mathrm{Cl}$, or several tens of ppm F, as reported in several studies [Sigvaldason and Oskarsson, 1986; Kent et al., 1999; Nielsen et al., 2000; Hauri, 2002], might add to the variability, but are insufficient to create the enrichment observed in the Izu HRA. Other studies, however, suggest an increase in $\mathrm{Cl}$ by 1 to 2 wt.\%; i.e., the amount of $\mathrm{Cl}$ presumed to be assimilated is higher than the total $\mathrm{Cl}$ of the HRA ( $\sim 0.8 \mathrm{wt} \%)$ [Michael and Schilling, 1989; Kent et al., 2002; Lassiter et al., 2002]. If this amount of $\mathrm{Cl}$ was added to the normal-group glasses melt by means of a partial crustal melt, then the absence of any variation in the alkaline and alkaline earth 
elements (e.g., $\mathrm{Na}, \mathrm{K}, \mathrm{Rb}$ ) that are also enriched in seawater-derived fluids, is suspicious. Unfortunately, existing models of seawater assimilation in the intraplate and backarc basin environments are based primarily on $\mathrm{Cl}$ variability. The other light elements $(\mathrm{F}, \mathrm{Li}, \mathrm{B})$ are not considered. Without this additional information, a direct comparison to the genetic processes in the Izu arc volcanic front remains unsatisfactory. We note, however, that in a single case of contaminated intraplate basalts, where F was analyzed [Hauri, 2002], it appears that the $\mathrm{Cl}$ and $\mathrm{F}$ enrichments of the glasses are unrelated. Thus if assimilation creates diversity, how could it then produce the systematic, longlasting enrichments of $\mathrm{Cl}, \mathrm{F}$ and $\mathrm{Li}$ observed in the Izu VF glasses? Furthermore, the subducting slab is a known source of the elements $\mathrm{Cl}, \mathrm{Li}$ and $\mathrm{B}$ in arc magmas [Ito et al., 1983; Ryan and Langmuir, 1993; Cervantes and Wallace, 2003], and slab processing at the relevant temperatures and pressures should be capable of providing the systematic excess $\mathrm{Cl}, \mathrm{F}$ and Li observed both in the normalgroup glasses and the HRA.

\subsection{Mantle Sources of the Halogens and Li}

[18] According to current theory, several fluid sources are present in shallow subduction zones (Figure 8).

[19] 1. The "classic" slab fluid source is the metacrust, which consists of the metamorphosed subducting sediment (metasediment) and basaltic crust (metabasalt). Metacrust fluids are generated by the decay of hydrous phases (e.g., chlorite, serpentine, amphibole) during progressive slab metamorphism [e.g., Tatsumi and Eggins, 1995; Schmidt and Poli, 1998; Bebout et al., 1999]. The capacity of these fluids to extract nominally "fluidmobile" elements from the metacrust, however, is contested. Even if extraction appears to be efficient for some elements (e.g., B [Ryan and Langmuir, 1993; Ryan et al., 1995, 1996; Benton et al., 2001]), there is increasing evidence, from experiments and from field studies in metamorphic terrains, that larger amounts of both subducted $\mathrm{H}_{2} \mathrm{O}$ and potentially fluid-mobile LILE are buried in the slab itself by incorporation into the hydrous phases that appear at higher pressures, e.g., phen-

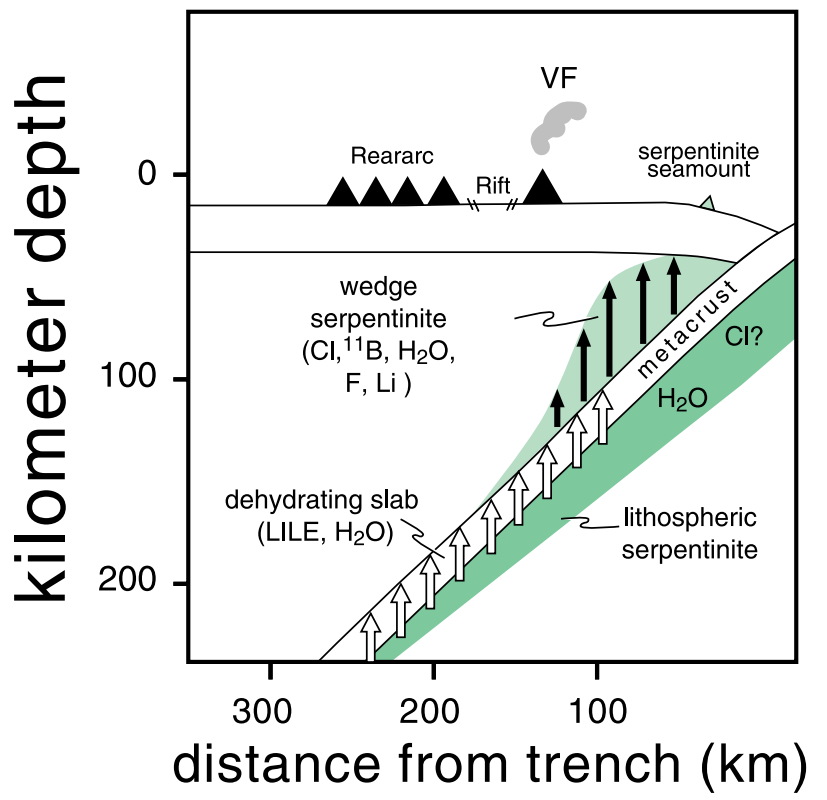

Figure 8. Cartoon illustrating the fluid sources and fluid distribution in shallow subduction zones, as discussed in the text. The hydrated wedge peridotite (light green) apparently forms beneath the forearc, and becomes down-dragged with the slab to arc front depth [e.g., Straub and Layne, 2002]. The serpentinized lithosphere (estimated thickness of $20 \mathrm{~km}$; darker green) forms outboard of the arc, in the oceanic basin, prior to subduction into the trench [Ranero et al., 2001].

gite, paragonite, lawsonite and epidote-group minerals [Schmidt, 1996; Schmidt and Poli, 1998; Bebout et al., 1999; Becker et al., 1999; Hermann and Green, 2001]. Only beyond arc front depths will the gradual destruction of these phases slowly release the elements that then control the chemistry of the slab components [Schmidt, 1996; Melzer and Wunder, 2000; Hermann and Green, 2001].

[20] 2. An alternative fluid source is the hydrated peridotite mantle above the metacrust (Tatsumi and Eggins [1995] and "wedge serpentinite" in Figure 8). The peridotite is hydrated trenchward from the VF by infiltration of slab fluids, and subsequently becomes down-dragged together with the metacrust. Tatsumi and coworkers [e.g., Tatsumi and Eggins, 1995; Kogiso et al., 1997; Tatsumi and Kosigo, 1997] suggest that the decay of amphibole at $\sim 75 \mathrm{~km}$ depth triggers substantial loss of fluidmobile LILE. The LILE are then trapped in new phases in the hydrated mantle above (e.g., phlogopite, pargasitic amphibole), and transported to arc 
front depths and beyond. This redistribution of the LILE, coupled with fractionation, is considered to control the trace element chemistry of the slab fluids [e.g., Kogiso et al., 1997]. A variant of this model suggests that the shallow slab fluids carry only a few, extremely fluid-mobile elements, such as B or Cl [Ryan et al., 2001; Straub and Layne, 2002], with the fluid-mobile LILE being largely retained in the slab. The extensively serpentinized mantle wedge was still down dragged with the metacrust to arc front depths, becoming the prime source of the isotopically heavy B that is observed in many arc lavas [Straub and Layne, 2002].

[21] 3. Irrespective of the presence of these first two fluid sources, the largest fluid volume might actually originate from the serpentinized lithospheric mantle of the subducting slab, below the metacrust (Ranero et al. [2001], Rüpke et al. [2002], "lithospheric serpentinite" in Figure 8). This serpentinized lithosphere, which may reach $20 \mathrm{~km}$ or more in thickness, forms prior to subduction by (1) the infiltration of seawater during deep hydrothermal circulation, at spreading centers and in the oceanic basins [e.g., Seyfried et al., 1984; Agrinier et al., 1988; Nielsen et al., 2000], or (2) along deep faults cutting through the oceanic crust during flexural up bending as the crust approaches the trenches [Peacock, 2001; Ranero et al., 2001]. Potentially, this process is very efficient in recycling elements that are readily dissolved in hydrothermal fluids and seawater (e.g., Cl, B, rare gases) back into the mantle [Rüpke et al., 2002; Scambelluri et al., 2001].

[22] In short, the fluid sources present beneath the Izu VF fall into two categories: (1) the metacrust, and (2) serpentinized (hydrated) upper mantle, located either above or below the metacrust (Figure 8). In contrast to the metacrust, which is highly enriched in all LILE, the serpentinized mantle is highly depleted, except for those elements that are added by the fluids. Apparently, the metacrust is then the most likely source of the LILE-rich fluids that infiltrated the mantle source of the normal-group glasses. However, the serpentinized mantle could produce the additional fluid component whose signal is preserved in the HRA. To date, there is no evidence to suggest wholesale transport of LILE from the oceanic crust or seawater into the mantle peridotite, which could in turn serve as the major source for the LILE-rich fluids. Field studies from the Mariana forearc serpentinites, from exhumed segments of the metacrust, and from the serpentinized upper mantle, all indicate that these contain only minor quantities of the fluid-mobile LILE relative to the metacrust [Ryan et al., 2001; Scambelluri et al., 2001]. For example, hydrated upper mantle exposed in the Alps usually has $<10 \mathrm{ppm} \mathrm{Sr}$ (and a maximum of 34 ppm Sr) [Scambelluri et al., 2001], well below the average of the metacrust ( $\sim 100 \mathrm{ppm} \mathrm{Sr})$. On the other hand, the serpentinized peridotite provides an excellent sink for a few highly fluid-mobile elements, such as $\mathrm{Cl}, \mathrm{F}$ and Li [Rucklidge and Patterson, 1977; Agrinier et al., 1988; Puga et al., 1999; Anselmi et al., 2000]. The $\mathrm{Cl}$ and $\mathrm{F}$ replace the $\left(\mathrm{OH}^{-}\right)$-groups in hydrous $\mathrm{Mg}$-silicates (e.g., serpentine and chlorite, or amphibole and phlogopite at greater depths), whereas the $\mathrm{Li}$ ion $\left(\mathrm{Li}^{+}\right)$substitutes for $\mathrm{Mg}^{2+}$. Studies show that modern and ancient oceanic serpentinites can contain several $1000 \mathrm{ppm}$ of $\mathrm{Cl}$ and $\mathrm{F}$, with maxima of $9000 \mathrm{ppm} \mathrm{Cl}$ and 3000 ppm F, respectively [Rucklidge and Patterson, 1977; Agrinier et al., 1988; Puga et al., 1999; Anselmi et al., 2000]. In contrast, the average metacrust contains only $\sim 113 \mathrm{ppm} \mathrm{Cl}$ and $\sim 241$ ppm F [e.g., Straub and Layne, 2003]. The serpentinite of the outer Mariana forearc contains 2-19 ppm Li [Benton et al., 1999] compared to an average upper mantle value of $\sim 1 \mathrm{ppm} \mathrm{Li} \mathrm{(Table} \mathrm{5).}$

\subsubsection{Lithospheric or Wedge Serpentinite as Fluid Source?}

[23] Of the two serpentinite reservoirs (lithospheric serpentinite and wedge serpentinite), the wedge serpentinite appears to be the most likely source of the HRA fluid component, for several reasons.

[24] First, the volumetric dominance of the normalgroup glasses relative to the HRA suggests that most of the total fluid volume that infiltrates the Izu VF mantle originates from the metacrust. The serpentinite must be a subsidiary fluid source. This characteristic appears to be more consistent with the wedge serpentinite, as the lithospheric serpentinite may produce an even larger fluid volume 


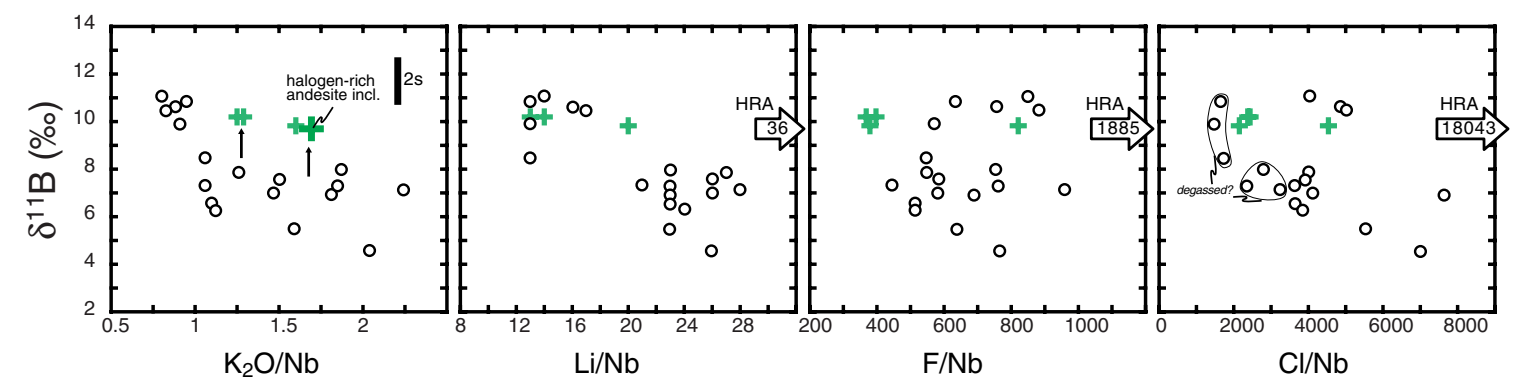

Figure 9. $\mathrm{K}_{2} \mathrm{O} / \mathrm{Nb}, \mathrm{Li} / \mathrm{Nb}, \mathrm{F} / \mathrm{Nb}$ and $\mathrm{Cl} / \mathrm{Nb}$ versus $\delta^{11} \mathrm{~B}$ of Izu glasses. For symbols see Figure $2 . \mathrm{K}_{2} \mathrm{O} / \mathrm{Nb}$ exemplifies the trends of LILE/Nb and $\mathrm{B} / \mathrm{Nb}$ in normal-group glasses (open circles; see Straub and Layne [2002, Figure 5]). HRA (bold green cross) and the mixed rhyolite inclusions (smaller green crosses) have slightly higher $\delta^{11} \mathrm{~B}$ values (indicated by black arrows) than the normal-group glasses (note that the $\mathrm{K}_{2} \mathrm{O}$ contents of HRA and normalgroup glasses are identical; see Figure 2), consistent with their origin from a high- $\delta{ }^{11} \mathrm{~B}$ source (i.e., wedge serpentinite with $\delta^{11} \mathrm{~B} \sim+15 \%$ [Straub and Layne, 2002]). Numbers within arrows give abundances (in ppm) of $\mathrm{Li}, \mathrm{F}$ and $\mathrm{Cl}$ in HRA, which plot outside the diagram. Note linear mixing trends defined by the HRA and the mixed rhyolites.

than the metacrust [Ranero et al., 2001; Rüpke et al., 2002].

[25] Second, any fluid from the lithospheric serpentinite must pass through the $\sim 6.4 \mathrm{~km}$ thick metacrust, from which it is very likely to scavenge additional elements [e.g., Rüpke et al., 2002]. Therefore if the lithospheric serpentinite was a significant fluid source, the fluid-mobile LILE and the halogens should be correlated, rather than the observed decoupling. If the lithospheric serpentinite was the HRA fluid source, then the decoupling is particularly difficult to explain for $\mathrm{Li}$, an element that is more abundant in the metacrust than in the serpentinite [e.g., Ryan and Langmuir, 1987]. A scenario in which the fluid from the lithospheric serpentinite passed through the metacrust along continuous cracks, or even through a slab window, is not consistent with the co-existence of the HRA and the normal-group glasses in crustal chambers, an observation that implies that the two fluid components must infiltrate the mantle source more or less simultaneously.

[26] Third, the normal-group Izu glasses display inverse correlations of $\delta^{11} \mathrm{~B}$ and LILE/ $\mathrm{Nb}$ ratios [Straub and Layne, 2002, Figure 5]. These inverse correlations provide a strong argument against both heavy B and the LILE being derived from the same fluid source. If the metacrust (or perhaps the lithospheric serpentinite) was the major source of heavy B, as suggested by several workers [e.g., Ishikawa et al., 2001; Tonarini et al., 2001; Rüpke et al., 2002], then $\delta^{11} \mathrm{~B}$ and LILE/Nb should be positively correlated. Moreover, at arc front depths, the metacrust apparently has $\delta^{11} \mathrm{~B}<0$, after having lost heavy B during shallow devolatilization [Peacock and Hervig, 1990; Straub and Layne, 2002]. If this is the case, then it appears likely that the lithospheric serpentinite is similarly depleted in heavy B at arc front depths. Therefore the most likely source of heavy B is, in fact, the wedge serpentinite, which became impregnated with ${ }^{11} \mathrm{~B}$ rich fluids trenchward of the Izu VF during shallow dewatering of the slab.

[27] In summary, the wedge serpentinite is the most likely source of the HRA fluid. Although this model does not preclude some lesser contribution of fluids from the lithospheric serpentinite, these "lithospheric" fluids are likely to completely mix with the metacrust fluids, forming a single, composite fluid of minor compositional variability.

\subsubsection{Relative Contributions of $\mathrm{Cl}, \mathrm{F}$ and Li From the Two Fluid Sources}

[28] Correlating $\mathrm{Cl}, \mathrm{F}$ and $\mathrm{Li}$ with $\delta^{11} \mathrm{~B}$ allows a first order estimate of the relative importance of the wedge serpentinite versus metacrust fluid sources for these elements at the Izu VF. This can be done because the Izu VF B originates in approximately equal amounts from the serpentinite wedge $(\sim 53 \%$ of $B$ ) and the metacrust ( $\sim 7 \%$ of $B)$ that have very different $\delta^{11} \mathrm{~B}$ values $(+14 \%$ and $+1 \%$, respectively [Straub and Layne, 2002]). Figure 9 
shows that the normal-group glasses are inversely correlated only in the $\mathrm{Li} / \mathrm{Nb}$ versus $\delta^{11} \mathrm{~B}$ space, suggesting that the fluid-transported $\mathrm{Li}$ - as $\mathrm{B}$ - was contributed both from the metacrust and the wedge serpentinite in about equal amounts. In contrast, $\mathrm{Cl} / \mathrm{Nb}$ and $\mathrm{F} / \mathrm{Nb}$ are uncorrelated with $\delta^{11} \mathrm{~B}$, even if some loss of $\mathrm{Cl}$ by degassing is taken into account (Figure 9). This lack of clear correlation with $\delta^{11} \mathrm{~B}$ suggests that $\mathrm{Cl}$ and $\mathrm{F}$ are supplied predominantly from only one of the two fluid sources, which should be the wedge serpentinite according to our model. This interpretation is supported by the elevated $\delta^{11} \mathrm{~B}$ values the HRA and the mixed rhyolite inclusions display relative to the normalgroup glasses, given the fact that both groups have similar $\mathrm{K}_{2} \mathrm{O}$ at a given $\mathrm{MgO}$ (Figure 9).

[29] Therefore if the wedge serpentinite is the dominant source of the fluid-transported $\mathrm{Cl}$ and $\mathrm{F}$ at the Izu VF, the contributions of $\mathrm{B}$ and $\mathrm{Li}$ from this reservoir must be less. A weaker relative fluid flux of $\mathrm{Li}$ from the wedge serpentinite is supported by the more moderate $\mathrm{Li}$ enrichment of the HRA compared to the halogens, and the lack of selective Li enrichment in a single HRA inclusion (Figure 2c). Further, the lack of a selective B enrichment in the HRA implies that the relative B flux from the wedge serpentinite is even somewhat less than the relative flux of Li. Thus the B contribution from the serpentinite wedge is entirely concealed in the abundance data (but not in the B isotopes). Since $\sim 53 \%$ of the total B at the Izu VF is wedge-derived [Straub and Layne, 2002], more than $53 \%$ of the $\mathrm{Cl}, \mathrm{F}$ and $\mathrm{Li}$ must originate from the wedge serpentinite at the Izu VF, with only the remainder being contributed from the metacrust fluids.

\subsubsection{Formation of the Wedge Serpentinite}

[30] The Cl-, F- and Li-bearing wedge serpentinite is likely to form by fluid infiltration trenchward to the arc volcanic front. However, the joint infiltration of $\mathrm{Cl}, \mathrm{F}, \mathrm{Li}$ and heavy $\mathrm{B}$, beneath the outer forearc is not supported by the data from the Mariana serpentinite seamounts. These data show that only $\mathrm{B}$ and possibly $\mathrm{Cl}$ are removed substantially at these depths $(\sim 20-25 \mathrm{~km})$. Note that despite being less saline than seawater (19500 ppm Cl) - the fluids upwelling beneath the outer
Mariana forearc are still rich in $\mathrm{Cl}$, with abundances ranging from 9900 to $18550 \mathrm{ppm} \mathrm{Cl}$ [Fryer et al., 1999; Benton et al., 2001], which could be due to $\mathrm{Cl}$ addition from slab. On the other hand, and despite the elevated Li of the Mariana serpentinites ( 2-19 ppm [Benton et al., 1999]), the Mariana forearc fluids carry only minor $\mathrm{Li}(\sim 1-2 \mathrm{ppm}$ [Ryan et al., 2001]) relative to the amounts present in the metacrust (several tens of ppm [Ryan and Langmuir, 1987]). This observation is consistent with the lower mobility of $\mathrm{Li}$ relative to $\mathrm{B}$ in hydrothermal experiments at $150^{\circ}$ to $375^{\circ} \mathrm{C}$ [Seyfried at al., 1984]. Nothing yet is known about the $\mathrm{F}$ contents of these shallow fluids, but $\mathrm{F}$ is expected in slab fluids, since it becomes highly fluid-mobile at temperatures $>250^{\circ} \mathrm{C}$ [Seyfried and Ding, 1995]. A simple explanation to reconcile these disparities was that the mobilities of $\mathrm{Cl}, \mathrm{F}$ and $\mathrm{Li}$ in fluids increase with increasing slab depth, in order to account for their abundance in the wedge peridotite. In this context, the joint enrichment of $\mathrm{Cl}, \mathrm{F}$ and Li might be significant, given the fact that these elements are all hosted in amphibole, which is the major metamorphic phase in the subducting crust [e.g., Tatsumi and Eggins, 1995]. In the metacrust, amphibole becomes unstable at $\sim 70$ to $80 \mathrm{~km}$ [Schmidt and Poli, 1998], still trenchward to the arc volcanic front. Hence amphibole should be an excellent source of $\mathrm{Cl}, \mathrm{F}$ and $\mathrm{Li}$ in slab fluids. However, the other phases, such as phengite, might release one or more of these elements as well, as they gradually release elements with depth [e.g., Bebout et al., 1999].

[31] Figure 10 attempts to summarize the above discussion in terms of "fluid release curves." Note that the lithospheric serpentinite is shown as an additional source of fluids to the wedge. We suggest that the release curves of $\mathrm{B}$ and $\mathrm{Cl}$ peak early, but then decline with increasing depth toward the rear arc. This is in agreement with models that propose that $\mathrm{B}$ and $\mathrm{Cl}$ become rapidly scavenged from the subducting slab during early subduction, which in turn prevents these elements from being recycled back into mantle [Ito et al., 1983; Ryan and Langmuir, 1993; Ryan et al., 1995, 1996; Bebout et al., 1999; Straub and Layne, 2003]. In contrast to $\mathrm{B}$ and $\mathrm{Cl}$, the fluid release 


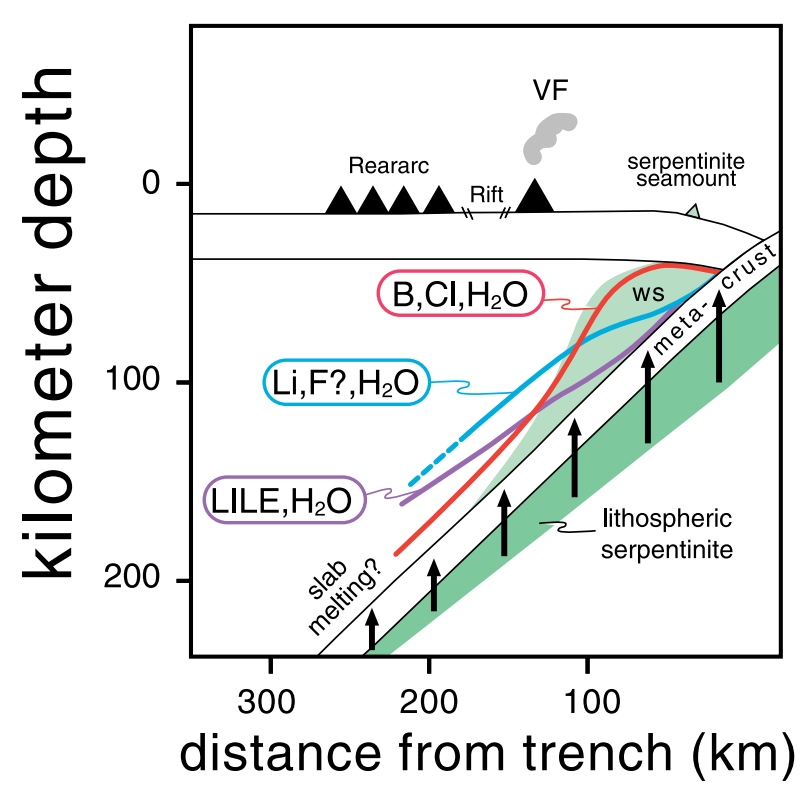

Figure 10. Cartoon to illustrate the 'fluid release curves' discussed in the text. WS = wedge serpentinite. The lithospheric serpentinite is shown as an additional fluid source next to the metacrust. Three successive fluid release curves are suggested; for $\mathrm{B}$ and $\mathrm{Cl}$ (red), $\mathrm{Li}$ and possibly $\mathrm{F}$ (blue), and the fluid-mobile LILE (lilac). Water is implied to be released continuously from slab.

curves of $\mathrm{Li}$ and $\mathrm{F}$, the latter being very speculative, are shown to increase with increasing slab depth, and, at least in the case of $\mathrm{Li}$, may extend beyond arc front depth [Paquin and Altherr, 2002]. Despite the evidence for fluid removal of $\mathrm{Li}$ and $\mathrm{F}$ from the slab, however, it is important to keep in mind that the relative amount removed from the slab is probably minor ( $<10 \%$ of slab $\mathrm{Li}$ and $\mathrm{F})$, as indicated by mass balance models [Ryan et al., 2001; Straub and Layne, 2003], and the study of metamorphic complexes [Bebout et al., 1999]. This might reflect the fact that most of $\mathrm{F}$ and $\mathrm{Li}$ are stored in anhydrous phases, replacing $\mathrm{Mg}^{+}$and $\mathrm{O}^{2-}$ [e.g., Paquin and Altherr, 2002]. Their incorporation into the mineral structure should protect these elements from entrainment into fluids, and they may only become substantially mobilized in partial slab melts that form well beyond arc front depths [e.g., Bebout et al., 1999; Plank and Kelley, 2001]. Finally, the release of the fluid-mobile LILE, the curve is drawn as single line for simplicity, appears to be negligible trenchward from the Izu VF as well, and increases only significantly at arc front depths.

\section{Some Implications of the Model Proposed}

[32] The fluid release model proposed here has several implications. Importantly, it supports the studies of Bebout et al. [1999] and Ryan et al. [2001] in proposing that the loss of many fluidmobile LILE is insignificant during early slab devolatilization. In the case of the "cool" Izu Bonin subduction zone, this apparently includes Cs as well, whereby Cs might be mobilized to a larger extent in subduction zones with higher thermal gradients [Bebout et al., 1999]. The fluid-mobile LILE are largely sequestered in the hydrous minerals, such as phengite, lawsonite, epidote, clinozoisite and zoisite, that sequentially stabilize with progressive metamorphism [Schmidt, 1996; Becker et al., 1999; Melzer and Wunder, 2000]. Consequently, the elemental and isotopic signatures of even highly fluid-mobile elements like $\mathrm{Cs}, \mathrm{Pb}$ or $\mathrm{Sr}$ should be largely preserved in the subducted materials until arc front depths. This validates many earlier studies on elemental recycling in arcs, in which this assumption is implicit [e.g., Elliott et al., 1997; Patino et al., 2000; Hochstaedter et al., 2001].

[33] Another aspect concerns the experimental studies of Keppler and Wyllie [1990] and Keppler [1996] that predict a critical role for the $\mathrm{Cl}$ and $F$ of slab fluids. These studies suggest that, owing to their capacity for complexing, Cl- and F-bearing fluids are capable of fractionating the fluid-mobile LILE from $\mathrm{Nb}$ and Ta. They may also fractionate $\mathrm{U}$ from Th, generating a typical "arc signature" [Keppler and Wyllie, 1990; Keppler and Wyllie, 1991; Keppler, 1996]. At first glance, this hypothesis appears to be supported since the Cl- and Frich slab fluids beneath the Izu VF have exactly the chemical characteristics (elevated LILE/ $\mathrm{Nb}$ and U/Th) predicted by this model [Hochstaedter et al., 2001; Straub et al., submitted manuscript, 2003]. However, the selective mobilization of halogens and Li documented by the HRA clearly does not support a key role for the halogens in 
elemental fractionation. Rather, it suggests that slab devolatilization was a multistep process, during which fluid release was controlled by the fluid-mobility of the individual elements, resulting in the depth-dependent, en echelon fluid release curves depicted in Figure 10, and in the fractionation of $\mathrm{Cl}, \mathrm{F}, \mathrm{Li}$ and $\mathrm{B}$ from the other fluidmobile LILE. If the $\mathrm{Cl}$ flux indeed decreases, as indicated in Figure 10, the role of $\mathrm{Cl}$ in controlling the fractionation of the elements mobilized in the deeper fluids is even more doubtful. Thus without ruling out halogen-complexing completely, it appears that the sequential formation and decay of metamorphic mineral phases exerts a stronger role as to fractionating elements during slab devolatilization.

\section{Conclusions}

[34] Four primary conclusions may be drawn from this study.

[35] 1. The Izu VF volcanics contain a subordinate component melt that is selectively enriched in $\mathrm{Cl}, F$ and Li. Despite being preserved only in very rare melt inclusions this halogen-rich andesite ("HRA") component melt appears to be a common constituent of the Izu VF magmas.

[36] 2. The HRA component melt is interpreted to reflect the presence of a subordinate fluid component in the Izu VF magma source that is derived, at arc front depths, from the "wedge serpentinite" above the metacrust. The major portion of this fluid, which transports the fluid-mobile LILE (K, $\mathrm{Sr}, \mathrm{Rb}, \mathrm{Cs}, \mathrm{Ba}, \mathrm{Pb}, \mathrm{U})$, originates from the metacrust, with a possible contribution from the lithospheric serpentinite below the metacrust.

[37] 3. This interpretation implies that slab fluids entrain only a few elements $(\mathrm{Cl}, \mathrm{B}$, and minor amounts of $\mathrm{F}$ and $\mathrm{Li}$ ) during shallow subduction, trenchward from the VF of the "cool" Izu subduction zone. Most of the fluid-mobile LILE (K, Sr, $\mathrm{Rb}, \mathrm{Cs}, \mathrm{Ba}, \mathrm{Pb}, \mathrm{U}$ ) appear to be retained in the slab until arc front depths.

[38] 4. Elemental fractionation by halogen-complexing appears to play a minor role compared to the sequential formation and decay of metamor- phic mineral phases during progressive slab metamorphism.

\section{Acknowledgments}

[39] The 782A tephra was made available to SMS through the Ocean Drilling Program. Charlie Langmuir and Klaus Wallmann are thanked for clarifying discussion. Jeff Ryan and an anonymous reviewer are thanked for formal journal reviews, and Gray Bebout and Bill White for constructive editorial comments. These all greatly improved the paper. Funding by the Deutsche Forschungsgemeinschaft (grant Str 441/4) and the National Science Foundation (grant EAR990440 to the Northeast National Ion Microprobe Facility at WHOI) is gratefully acknowledged.

\section{References}

Agrinier, P., C. Mevel, and J. Girardeau, Hydrothermal alteration of the peridotites cored at the ocean/continent boundary of the Iberian margin: Petrologic and stable evidence, Proc. Ocean Drill. Program Sci. Results, 103, 225-233, 1988.

Anselmi, B., M. Mellini, and C. Viti, Chlorine in the Elba Livornesi and Murlo serpentintes: Evidence for seawater interaction, Eur. J. Mineral., 12, 137-146, 2000.

Bebout, G. E., J. G. Ryan, W. P. Leeman, and A. E. Bebout, Fractionation of trace elements by subduction-zone metamorphism: Effect of convergent-margin thermal evolution, Earth Planet. Sci. Lett., 171, 63-81, 1999.

Becker, H., K. P. Jochum, and R. W. Carlson, Constraints from high-pressure veins in eclogites on the composition of hydrous fluids in subduction zones, Chem. Geol., 160, 291308, 1999.

Benton, L. D., I. P. Savov, and J. G. Ryan, Recycling of subducted lithium in forarcs: Insights from a serpentinite seamount, Eos Trans. AGU, 80(17), Spring Meeting, S349, 1999.

Benton, L. D., J. G. Ryan, and F. Tera, Boron isotope systematics of slab fluids as inferred from a serpentine seamount, Mariana forearc, Earth Planet. Sci. Lett., 187, 273-282, 2001.

Bryant, C. J., R. J. Arculus, and S. M. Eggins, Laser ablationinductively coupled plasma-mass spectrometry and tephras: A new approach to understanding arc magma genesis, Geology, 27, 1119-1122, 1999.

Carmichael, I. S. E., The andesite aqueduct: Perspectives on the evolution of intemediate magmatism in west-central (105-99 ${ }^{\circ}$ W) Mexico, Contrib. Mineral. Petrol., 143, $641-$ 663, 2002.

Cervantes, P., and P. J. Wallace, The role of $\mathrm{H}_{2} \mathrm{O}$ in subduction zone magmatism: New insights from melt inclusions in high$\mathrm{Mg}$ basalts from central Mexico, Geology, 31, 235-238, 2003.

Class, C., D. M. Miller, S. L. Goldstein, and C. H. Langmuir, Distinguishing melt and fluid subduction components in Umnak volcanics, Aleutian Arc, Geochem. Geophys. Geosyst., 1, Paper number 1999GC000010, 2000. 
Decitre, S., E. Deloule, L. Reisberg, R. James, P. Agrinier, and C. Mével, Behavior of $\mathrm{Li}$ and its isotopes during serpentinization of oceanic peridotites, Geochem. Geophys. Geosyst., 3(1), 1007, doi:10.1029/2001GC000178, 2002.

Elliott, T., T. Plank, A. Zindler, W. White, and B. Bourdon, Element transport from subducted slab to juvenile crust at the Mariana arc, J. Geophys. Res., 102, 14,991-15,019, 1997.

Ewart, A., and C. J. Hawkesworth, The Pleistocene-Recent Tonga-Kermadec arc lavas: Interpretation of new isotopic and rare earth data in terms of a depleted mantle source model, J. Petrol., 28, 495-530, 1987.

Fisk, M., and K. A. Kelley, Probing the Pacific's oldest MORB glass: Mantle chemistry and melting conditions during the birth of the Pacific Plate, Earth Planet. Sci. Lett., 202, $741-$ 752, 2002.

Fryer, P., C. G. Wheat, and M. J. Mottl, Mariana blueschist mud volcanism; implications for conditions within the subduction zone, Geology, 27, 103-106, 1999.

Hauri, E., SIMS analysis of volatiles in silicate glasses: 2 . Isotopes and abundances in Hawaiian melt inclusions, Chem. Geol., 183, 115-142, 2002.

Hermann, J., and D. H. Green, Experimental constraints on high pressure melting in subducted crust, Earth Planet. Sci. Lett., 188, 149-168, 2001.

Hirose, K., Melting experiments on lherzolite KLB-1 under hydrous conditions and generation of high-magnesian andesitic melts, Geology, 25, 42-44, 1997.

Hochstaedter, A. F., J. B. Gill, B. Taylor, O. Ishizuka, M. Yuasa, and S. Morita, Across-arc geochemical trends in the Izu-Bonin arc: Constraints on source composition and mantle melting, J. Geophys. Res., 105, 495-512, 2000.

Hochstaedter, A. G., J. B. Gill, R. Peters, P. Broughton, P. Holden, and B. Taylor, Across-arc geochemical trends in the Izu-Bonin arc: Contributions from the subducting slab, Geochem. Geophys. Geosyst., 2, Paper number 2000GC000105, 2001.

Ishikawa, T., F. Tera, and T. Nakazawa, Boron isotope and trace element systematics of the three volcanic zones in the Kamchatka arc, Geochim. Cosmochim. Acta, 62, 45234537, 2001.

Ito, E., D. Harris, and A. T. Anderson, Alteration of oceanic crust and geologic cycling of chlorine and water, Geochim. Cosmochim. Acta., 47, 1613-1624, 1983.

Katsumata, M., and L. R. Sykes, Seismicity and tectonics of the Western Pacific: Izu-Mariana-Caroline and RyukyuTaiwan Regions, J. Geophys. Res., 74, 5923-5949, 1969.

Kent, A. J. R., D. A. Clague, M. Honda, E. M. Stolper, I. D. Hutcheson, and M. D. Norman, Widespread assimilation of a sea-water derived component at Loihi Seamount, Hawaii, Geochim. Cosmochim. Acta, 63, 2749-2761, 1999.

Kent, A. J. R., D. W. Peate, S. Newman, E. Stolper, and J. A. Pearce, Chlorine in submarine glasses from the Lau Basin: Seawater contamination and constraints on the composition of slab-derived fluids, Earth Planet. Sci. Lett., 202, 361377, 2002.
Keppler, H., Constraints from partitioning experiments on the composition of subduction zone fluids, Nature, 380, 237240, 1996.

Keppler, H., and P. J. Wyllie, Role of fluids in transport and fractionation of uranium and thorium in magmatic processes, Nature, 348, 531-533, 1990.

Keppler, H., and P. J. Wyllie, Partitioning of Cu, Sn, Mo, W, U, and Th between melt and aqueous fluid in the systems haplogranite- $\mathrm{H}_{2} \mathrm{O}-\mathrm{HCl}$ and haplogranite- $\mathrm{H}_{2} \mathrm{O}-\mathrm{HF}$, Contrib. Mineral. Petrol., 109, 139-150, 1991.

Kerrick, D. M., and J. A. D. Connolly, Subduction of ophicarbonates and recycling of $\mathrm{CO}_{2}$ and $\mathrm{H}_{2} \mathrm{O}$, Earth Planet. Sci. Lett., 26, 375-378, 1998.

Kogiso, T., Y. Tatsumi, and S. Nakano, Trace element transport during dehydration processes in the subducted oceanic crust: 1. Experiments and implications for the origin of ocean basalts, Earth Planet. Sci. Lett., 148, 193-205, 1997.

Kohut, E. J., R. L. Nielsen, and S. H. Bloomer, Across and along arc variability in parental magmas of the southern marianas: Evidence from melt inclusion and mineral analyses, paper presented at NSF-IFREE MARGINS Subduction Factory Izu-Bonin-Mariana Arc workshop, NSF-IFREE, Honolulu, Hawaii, 2002.

Langmuir, C. H., Y. Zhang, B. Taylor, T. Plank, J. Rubenstone, and A. Schmidt, Petrogenesis of Torishima and adjacent volcanoes of the Izu-Bonin arc: One end member of the global spectrum of arc basalts compositions, Contrib. Mineral. Petrol, in press, 2003.

Lassiter, J. C., E. H. Hauri, I. K. Nikogosian, and H. G. Barsczus, Chlorine-potassium variations in melt inclusions from Raivavae and Rapa, Austral Isalnds: Constraints on chlorine recycling in the mantle and evidence for brine-induced melting of oceanic crust, Earth Planet. Sci. Lett., 202, 525-540, 2002.

Melzer, S., and B. Wunder, Island-arc basalt alkali ratios: Constraints from phengite-fluid partionining experiments, Geology, 28, 583-586, 2000.

Michael, P. J., and W. C. Cornell, Influence of spreading rate and magma supply on crystallization and assimiliation beneath mid-ocean ridges: Evidence from chlorine and major element chemistry of mid-ocean ridge basalts, J. Geophys. Res., 103, 18,325-18,356, 1998.

Michael, P. J., and J. G. Schilling, Chlorine in mid-ocean ridge magmas: Evidence for assimilation of seawater-influenced components, Geochim. Cosmochim., 53, 3131-3134, 1989.

Miller, D. M., C. H. Langmuir, S. L. Goldstein, and A. L. Franks, The importance of parental magma composition to calc-alkaline and tholeiitic evolution: Evidence from Umnak Island in the Aleutians, J. Geophys. Res., 97, 321-343, 1992.

Nielsen, R. L., R. E. Sours-Page, and K. S. Harpp, Role of a Cl-bearing flux in the origin of depleted ocean floor magmas, Geochem. Geophys. Geosys., 1, Paper number 1999GC000017, 2000.

Paquin, J., and R. Altherr, Subduction-related lithium metasomatism during exhumation of the Alpe Arami ultrahigh-pressure garnet peridotite (Central Alps, Switzerland), Contrib. Mineral. Petrol., 143, 623-640, 2002. 
Patino, L. C., M. J. Carr, and M. D. Feigenson, Local and regional variation in Central American arc lavas controlled by variations in subducted sediment input, Contrib. Mineral. Petrol., 138, 265-283, 2000.

Peacock, S. M., Are the lower planes of double seismic zones caused by serpentine dehydration in subducting oceanic mantle, Geology, 29, 299-302, 2001.

Peacock, S., and R. L. Hervig, Boron isotopic composition of subduction-zone metamorphic rocks, Chem. Geol., 160, 281-290, 1990.

Plank, T., and K. Kelley, Contrasting sediment input and output at the Izu and Mariana subduction factories, Eos Trans. $A G U, 82(47)$, Fall Meet. Suppl., Abstract T22D10, 2001

Plank, T., and C. H. Langmuir, An evaluation of the global variations in the major element chemistry of arc basalts, Earth Planet. Sci. Lett., 90, 349-370, 1988.

Plank, T., J. N. Ludden, and C. Escutia, Proceedings of the Ocean Drilling, Initial Reports, vol. 185, Ocean Drill. Program, College Station, Tex., 2000.

Puga, E., J. M. Nieto, A. D. Federico, J. L. Bodinier, and L. Morton, Petrology and metamorphic evolution of ultramafic rocks and dolerite dykes of the Betic Ophiolitic association Mulhacen complex, SE Spain: Evidence of eo-Alpine subduction following an ocean-floor metasomatic process, Lithos, 49, 23-56, 1999.

Ranero, C. R., J. P. Morgan, K. D. McIntosh, and C. Reichert, Flexural faulting and mantle serpentinization at the Middle American Trench, Eos Trans. AGU, 82(47), Fall Meet. Suppl., Abstract T22D-04, 2001.

Rucklidge, J. C., and G. C. Patterson, The role of chlorine in serpentinization, Contrib. Mineral. Petrol., 65, 39-44, 1977.

Rüpke, L. H., J. Phipps Morgan, M. Hort, and J. A. D. Connolly, Are the regional variations on Central American arc lavas due to differing basaltic versus peridotitic slab sources of fluids?, Geology, 30, 1035-1038, 2002.

Ryan, J. G., and C. H. Langmuir, The systematics of lithium abundances in young volcanic rocks, Geochim. Cosmochim. Acta, 51, 1727-1741, 1987.

Ryan, J. G., and C. H. Langmuir, The systematics of boron abundances in young volcanic rocks, Geochim. Cosmochim. Acta, 57, 1489-1498, 1993.

Ryan, J. G., J. Morris, F. Tera, W. P. Leeman, and A. Tsvetkov, Cross-arc geochemical variations in the Kurile Arc as a function of slab depth, Science, 270, 625-627, 1995.

Ryan, J. G., J. Morris, G. E. Bebout, and W. P. Leeman, Describing chemical fluxes in subduction zones: Insights from "Depth-Profiling" studies of arc and forearc rocks, in Subduction: Top to Bottom, Geophys. Monogr. Ser., vol. 96, edited by G. E. Bebout, pp. 263-268, AGU, 1996.

Ryan, J. G., L. D. Benton, and I. P. Savov, Isotopic and elemental signatures of the forearc, and impacts on subduction recycling: Evidence from the Marianas, Eos Trans. $A G U$, 82(47), Fall Meet. Suppl., Abstract V11B-11, 2001.

Scambelluri, M., E. Rampone, and G. B. Piccardo, Fluid and element cycling in subducted serpentinite: A trace-element study of the Erro-Tobbio high-pressure ultramafites (Western Alps, NW Italy), J. Petrol., 42, 55-67, 2001.
Schilling, J. G., C. K. Unni, and M. L. Bender, Origin of chlorine and bromine in the oceans, Nature, 273, 631636, 1978.

Schmidt, A., Temporal and Spatial Evolution of the Izu Island Arc, Japan, in Terms of Sr-Nd-Pb Isotope Geochemistry, Doctoral Thesis; 81 p., 2001. (Available at http://e-diss. uni-kiel.de/diss_465/)

Schmidt, M. W., Experimental constraints on recycling of potassium from subducted oceanic crust, Science, 272, $1927-$ 1929, 1996.

Schmidt, M. W., and S. Poli, Experimentally based water budgets for dehydrating slabs and the consequences for arc magma generation, Earth Planet. Sci. Lett., 163, $361-$ 379, 1998.

Seyfried, W. E., and K. Ding, The hydrothermal chemistry of fluoride in seawater, Geochim. Cosmochim. Acta, 59, $1063-$ 1071, 1995.

Seyfried, W. E., D. R. Janecky, and M. J. Mottl, Alteration of the oceanic crust, implications for geochemical cycles of lithium and boron, Geochim. Cosmochim. Acta, 48, 557569, 1984.

Sigvaldason, G. E., and N. Oskarsson, Fluorine in basalts from Iceland, Contrib. Mineral. Petrol., 94, 263-271, 1986.

Sisson, T. W., and G. D. Layne, $\mathrm{H}_{2} \mathrm{O}$ in basalt and basaltic andesite glass inclusions from four subduction-related volcanoes, Earth Planet. Sci. Lett., 117, 619-635, 1993.

Straub, S. M., and G. D. Layne, The systematics of boron isotopes in Izu arc front volcanic rocks, Earth Planet. Sci. Lett., 198, 25-39, 2002.

Straub, S. M., and G. D. Layne, The systematics of chlorine, fluorine and water in Izu arc front volcanic rocks: Implications for volatile cycling in subduction zones, Geochim. Cosmochim. Acta, in press, 2003.

Suheyiro, K., N. Takahashi, Y. Ariie, Y. Yokoi, R. Hino, M. Shinohara, T. Kanazawa, N. Hirata, H. Tokuyama, and A. Taira, Continental crust, crustal underplating, and low-Q upper mantle beneath an oceanic island arc, Science, 272, 390-392, 1996.

Sun, S. S., and W. F. McDonough, Chemical and isotopic systematics of oceanic basalts: Implications for mantle composition and processes, in Magmatism in the Ocean Basins, edited by A. D. Saunders and M. J. Norry, pp. 313-345, Blackwell Sci., Malden, Mass., 1989.

Tamura, Y., and Y. Tatsumi, Remelting of an andesitic crust as a possible origin for rhyolitic magma in oceanic arcs: An example from the Izu-Bonin Arc, J. Petrol., 43, 10291047, 2002.

Tatsumi, Y., and E. Eggins, Subduction Zone Magmatism, 211 pp., Blackwell Sci., Malden, Mass., 1995.

Tatsumi, Y., and T. Kosigo, Trace element transport during dehydration processes in the subducted oceanic crust: 2 . Origin of chemical and physical characteristics in arc magmatism, Earth Planet. Sci. Lett., 148, 207-221, 1997.

Taylor, B., Rifting and the volcanic-tectonic evolution of the Izu-Bonin-Mariana Arc, Proc. Ocean Drill. Program Sci. Results, 126, 627-651, 1992. 
Taylor, R. N., and R. W. Nesbitt, Isotopic characteristics of subduction fluids in an intra-oceanic setting, Izu-Bonin-Arc, Japan, Earth Planet. Sci. Lett., 164, 79-98, 1998.

Tonarini, S., W. P. Leeman, and G. Ferrara, Boron isotopic variations in lavas of the Aeolian volcanic arc, South Italy, J. Volcanol. Geotherm. Res., 110, 155-170, 2001.

Von Damm, K. L., Controls on the chemistry and temporal variability of seafloor hydrothermal fluids, in Seafloor $\mathrm{Hy}$ drothermal Systems: Physical, Chemical, Biological and Geological Interactions, Geophys. Monogr. Ser., vol. 91, edited by S. E. Humphris et al., pp. 222-247, AGU, Washington, D. C., 1995.

Wallmann, K., The geological water cycle and the evolution of marine $\delta^{11} \mathrm{O}$ values, Geochim. Cosmochim. Acta, 65, 24692485, 2001.

Wicks, C. W., and M. A. Richards, A detailed map of the 660kilometer discontinuity beneath the Izu-Bonin subduction zone, Science, 261, 1424-1427, 1993.

$\mathrm{Xu}$, Y., and S. W. Wise, Middle Eocene to Miocene calcareous nannofossils of Leg 125 from the western Pacific Ocean, Proc. Ocean Drill. Program Sci. Results, 125, 43-70, 1992. 